Climate Change Expert Group

Paper No. 2013(3)

\title{
Establishing and \\ Understanding Post-2020 \\ Climate Change Mitigation \\ Commitments
}

Gregory Briner and Andrew Prag (OECD) 


\section{OECD/IEA CLIMATE CHANGE EXPERT GROUP PAPERS}

This series is designed to make available to a wider readership selected papers on climate change issues that have been prepared for the OECD/IEA Climate Change Expert Group (CCXG). The CCXG (formerly called the Annex I Expert Group) is a group of government delegates from OECD and other industrialised countries. The aim of the group is to promote dialogue and enhance understanding on technical issues in the international climate change negotiations. CCXG papers are developed in consultation with experts from a wide range of developed and developing countries, including those participating in CCXG Global Forums.

The full papers are generally available only in English.

The opinions expressed in these papers are the sole responsibility of the author(s) and do not necessarily reflect the views of the OECD, the IEA or their member countries, or the endorsement of any approach described herein.

Comments on the series are welcome, and should be sent to env.contact@oecd.org or the Environment Directorate, 2 rue André Pascal, 75775 PARIS CEDEX 16, France.

OECD/IEA Climate Change Expert Group Papers are published on www.oecd.org/env/cc/ccxg.htm

Applications for permission to reproduce or translate all or part of this material should be made to: OECD Publishing, rights@oecd.org or fax 33145249930.

This document has been produced with the financial assistance of the European Union. The views expressed herein can in no way be taken to reflect the official opinion of the European Union.

Copyright OECD/IEA, 2013

Applications for permission to reproduce or translate all or part of this material should be addressed to:

Head of Publications Service, OECD/IEA

2 rue André-Pascal, 75775 Paris Cedex 16, France

or

9 rue de la Fédération, 75739 Paris Cedex 15, France. 


\begin{abstract}
A new international climate change agreement that will have legal force and be applicable to all countries is being negotiated under the auspices of the United Nations Framework Convention on Climate Change (UNFCCC). The agreement is to be adopted by 2015 and come into effect from 2020. An effective agreement would include quantitative mitigation commitments from all major emitters and result in concrete actions to reduce greenhouse gas emissions while catalysing long-term transformations to low-carbon and climate-resilient economies. The aim of this paper is to explore what mitigation commitments put forward under the 2015 agreement might look like, what guidance might be agreed regarding the type of commitments proposed, and which "rules of the game" would need to be agreed before draft commitments for the post-2020 period are put forward. The paper outlines what ex-ante information would need to be provided in order to understand commitments, and explores whether guidance could take the form of "bounded flexibility" for the various dimensions describing mitigation commitments in order to provide a basis for post-2020 emissions accounting and tracking progress. It also describes possible stages of the process for establishing commitments for the 2015 agreement.
\end{abstract}

JEL Classification: F53, O44, Q54, Q56

Keywords: climate change, mitigation, greenhouse gas, UNFCCC

\title{
RÉSUMÉ
}

Un nouvel accord international relatif au changement climatique, qui aura valeur juridique et s'appliquera à tous les pays, est en cours de négociation sous les auspices de la Convention-cadre des Nations Unies sur les changements climatiques (CCNUCC). Son adoption doit intervenir en 2015 au plus tard, et son entrée en vigueur en 2020. Pour porter ses fruits, cet accord devrait comporter des engagements quantitatifs d'atténuation pris par tous les gros émetteurs et donner lieu à des actions concrètes visant à réduire les émissions de gaz à effet de serre tout en catalysant des transformations à long terme qui aboutiront à des économies sobres en carbone et résilientes face au changement climatique. Ce rapport a pour objectif d'analyser à quoi pourraient ressembler les engagements d'atténuation qui seront proposés dans le cadre de l'accord de 2015, quelles orientations pourraient être décidées concernant le type d'engagements proposés, et quelles « règles du jeu » devraient être établies d'un commun accord avant que des engagements préliminaires ne soient formulés pour la période postérieure à 2020. Il décrit les informations à fournir au préalable pour que les engagements soient bien compris, et aborde la question de savoir si les orientations pourraient prendre la forme d'une « flexibilité encadrée » pour rendre compte des différents aspects des engagements d'atténuation afin de jeter les bases de la comptabilisation des émissions et du suivi des progrès réalisés après 2020. Il expose également les différentes étapes possibles du processus d'établissement des engagements en vue de l'accord de 2015.

Classification JEL: F53, O44, Q54, Q56

Mots-clés: changement climatique, atténuation, gaz à effets de serre, CCNUCC 


\section{FOREWORD}

This document was prepared by the OECD and IEA Secretariats in 2013 in response to a request from the Climate Change Expert Group (CCXG) on the United Nations Framework Convention on Climate Change (UNFCCC). The CCXG oversees development of analytical papers for the purpose of providing useful and timely input to the climate change negotiations. These papers may also be useful to national policy-makers and other decision-makers. Authors work with the CCXG to develop these papers in a collaborative effort. However, the papers do not necessarily represent the views of the OECD or the IEA, nor are they intended to prejudge the views of countries participating in the CCXG. Rather, they are Secretariat information papers intended to inform Member countries, as well as the UNFCCC audience.

Members of the CCXG are Annex I and OECD countries. The Annex I Parties or countries referred to in this document are those listed in Annex I of the UNFCCC (as amended by the Conference of the Parties in 1997 and 2010): Australia, Austria, Belarus, Belgium, Bulgaria, Canada, Croatia, Czech Republic, Denmark, the European Community, Estonia, Finland, France, Germany, Greece, Hungary, Iceland, Ireland, Italy, Japan, Latvia, Liechtenstein, Lithuania, Luxembourg, Malta, Monaco, the Netherlands, New Zealand, Norway, Poland, Portugal, Romania, the Russian Federation, Slovakia, Slovenia, Spain, Sweden, Switzerland, Turkey, Ukraine, the United Kingdom of Great Britain and Northern Ireland, and the United States of America. As OECD member countries, Korea, Mexico, Chile, and Israel are also members of the CCXG. Where this document refers to "countries" or "governments", it is also intended to include "regional economic organisations", if appropriate.

\section{ACKNOWLEDGEMENTS}

This paper was prepared by Gregory Briner and Andrew Prag (OECD). The paper benefited from direct funding for the work of the CCXG programme in 2013, including from Australia, the EC, Germany, Japan, Korea, the Netherlands, New Zealand, Norway, Sweden and Switzerland and the United Kingdom, and in-kind support from the OECD and the IEA.

The authors would like to acknowledge the helpful comments from their OECD/IEA colleagues Anthony Cox, Richard Baron, Randy Caruso, Jane Ellis, Takashi Hattori, Christina Hood, Raphaël Jachnik, Matthias Kimmel and Simon Upton, as well as Neta Meidav (UK) on earlier drafts. The authors gratefully acknowledge information provided by Dougal McInnes (Australia). The paper also benefited from participants' comments at the CCXG Global Forum event in September 2013, where a draft version of this paper was presented, as well as subsequent written comments from the governments of Belgium, Chile, the EC, France, Korea, the Netherlands, Sweden, the UK, and the US.

\section{Questions and comments should be sent to:}

Gregory Briner

OECD Environment Directorate

2, rue André-Pascal

75775 Paris Cedex 16

France

Email: gregory.briner@oecd.org

All OECD and IEA information papers for the Climate Change Expert Group on the UNFCCC can be downloaded from: http://www.oecd.org/env/cc/ccxg.htm. 
TABLE OF CONTENTS

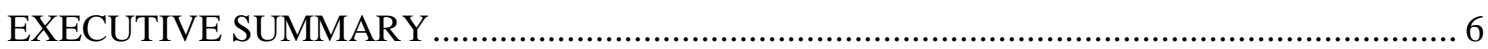

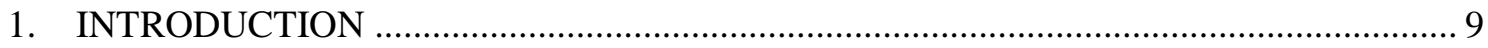

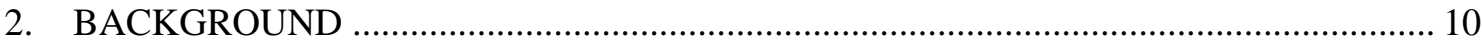

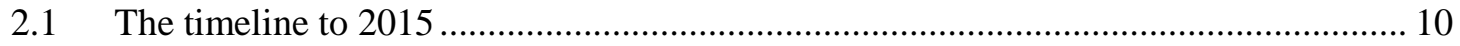

2.2 Existing pledges and different possible commitment types ............................................ 13

2.3 The multiple dimensions of mitigation commitments .................................................... 16

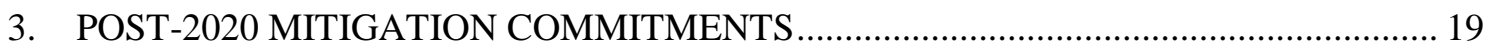

3.1 Bounded flexibility for post-2020 commitments ........................................................ 19

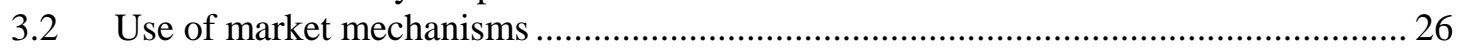

3.3 Ex-ante clarification of post-2020 commitments ......................................................... 26

4. POSSIBLE PROCESS FOR ESTABLISHING POST-2020 COMMITMENTS ................. 31

4.1 The multiple influences on mitigation commitments ..................................................... 31

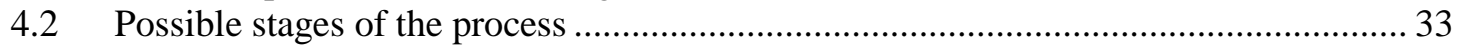

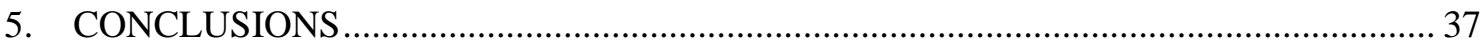

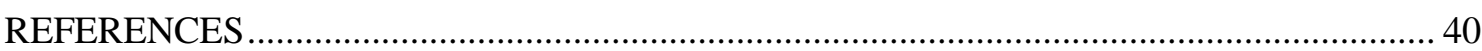

\section{LIST OF TABLES}

Table 1. Different commitment types and examples of existing pledges......................... 13

Table 2. Advantages and disadvantages of different commitment types .......................... 16

Table 3. Possible options for bounded flexibility for post-2020 commitments.................. 20

Table 4. Summary of ex-ante information needed to understand commitments ................ 27

\section{LIST OF FIGURES}

Figure 1. Timeline of selected key dates and events, 2013-15 (not comprehensive) ......... 12

Figure 2. Summary of 2020 pledge types .................................................................. 15

Figure 3. Some of the multiple dimensions of commitments: two hypothetical examples 18

Figure 4. Illustration of single year versus multiple-year period targets ............................. 23

Figure 5. Common international and domestic influences on mitigation commitments .... 32

Figure 6. $\quad$ A possible process with multiple stages ............................................................... 34 


\section{Executive summary}

A new international climate change agreement that has legal force and is applicable to all countries is currently being negotiated under the auspices of the United Nations Framework Convention on Climate Change (UNFCCC). The agreement is expected to address mitigation, adaptation, finance, technology, capacity building and transparency, and is due to be adopted at COP 21 in 2015 and come into effect from 2020. An effective agreement would include quantitative mitigation commitments ${ }^{1}$ from all major emitters and result in concrete actions to reduce greenhouse gas (GHG) emissions while catalysing long-term transformations to low-carbon and climate-resilient economies.

The aim of this paper is to explore what mitigation commitments put forward under the 2015 agreement might look like, what guidance might be needed regarding the type of commitments proposed, and what "rules of the game" would need to be agreed before draft commitments for the post-2020 period are put forward. The paper outlines what ex-ante information would need to be provided in order to understand commitments and provide a basis for post-2020 emissions accounting. The paper also describes possible stages of the process for establishing commitments for the 2015 agreement.

All Parties to the UNFCCC have agreed that the increase in global average temperature should be limited to below $2{ }^{\circ} \mathrm{C}$ above pre-industrial levels. In order to understand whether countries' commitments are collectively sufficient to provide a chance of meeting this long-term global goal, estimations of the future global GHG emissions trajectory are needed. The way in which post-2020 mitigation commitments are set and the accounting rules adopted will have an impact on the uncertainty associated with this trajectory. Post-2020 mitigation commitments will also need to send a strong and clear long-term signal to the private sector and other investors that governments remain committed to meeting the $2{ }^{\circ} \mathrm{C}$ goal.

At the same time, flexibility is needed to cater for the increasingly diverse national circumstances of different countries. Therefore different types of mitigation commitments are likely to be put forward for the post-2020 period; for example, commitments could be expressed using different metrics (e.g. total GHG emissions, GHG emissions per unit GDP, installed capacity of renewable energy, area of forest cover) and different coverage in terms of sectors and gases (e.g. economy-wide targets for all GHGs, goals for $\mathrm{CO}_{2}$ only in one sector, project-level actions). If all major emitters were to propose quantitative commitments in GHG terms, this would make it easier to measure progress towards both individual and global commitments.

There is always some uncertainty associated with ex-ante estimates of future emissions levels. However, some types of mitigation commitment create more uncertainty and pose greater accounting challenges than others. For example, if commitments are expressed relative to business-as-usual (BAU) levels then significant uncertainty can remain regarding the expected emissions level in the target year - particularly if the BAU baseline has not been published, or if the baseline has been published but may be revised before the target year. Intensity commitments (e.g. GHG emissions per unit Gross Domestic Product) link GHG outcomes to future GDP levels, which are difficult to predict. Commitments expressed in non-GHG terms (e.g. percentage of renewable energy in the energy mix) can be converted into GHG terms, but the assumptions involved in this conversion process are a further source of uncertainty. These sources of uncertainty are not an issue for commitments expressed in terms of total GHG emissions relative to a base year.

\footnotetext{
${ }^{1}$ Various terms have been used in this context by different countries, including "commitments", "contributions", "offers", "targets" and "actions". The term "commitment" is used in this paper.
} 
There can be a link between the level of ambition of mitigation commitments and the accounting approach used. This is because mitigation commitments have multiple dimensions such as the time frame, base year, coverage of sectors and gases, treatment of emissions and sinks from the land sector (if included in the coverage), and global warming potentials (GWPs) or other GHG-equivalence metric used, as well as use of units from market mechanisms. Figure ES.1 provides an example of one way to visualise the multiple dimensions of two or more mitigation commitments. In addition to these dimensions, the level of ambition of mitigation commitments depends on the national circumstances of the country concerned.

Figure ES.1: Some of the multiple dimensions of commitments: two hypothetical examples

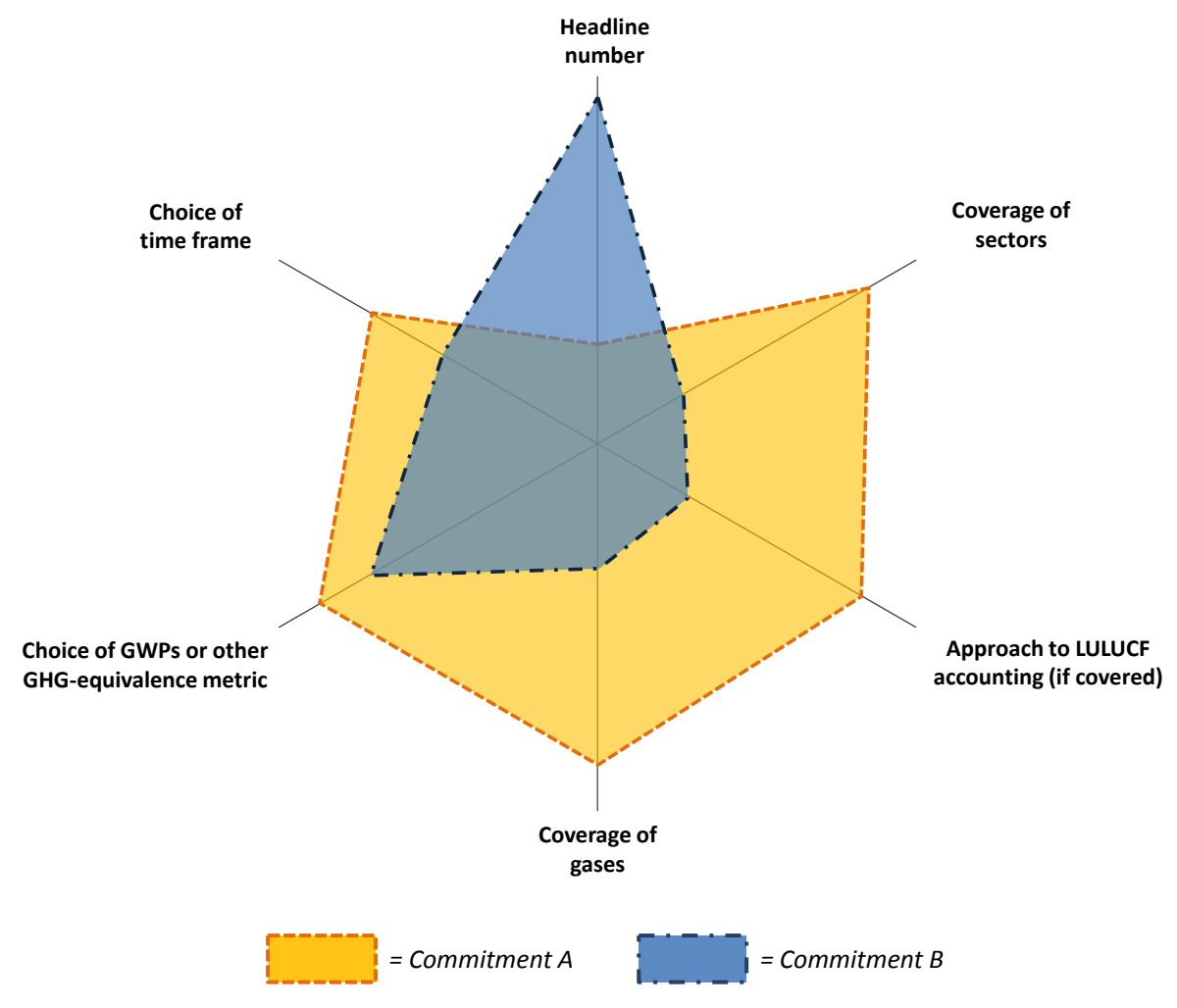

The new agreement could include the concept of "bounded flexibility". In this paper, the term bounded flexibility means that Parties could agree on the values or ranges of values to be used for some of the dimensions of mitigation commitments, while maintaining flexibility for other aspects. The rationale for introducing bounded flexibility includes both technical and political reasons. On the technical side, having an internationally-agreed timeframe for commitments can make it easier to compare progress towards goals, reduce uncertainty associated with future emissions levels and simplify the operation of cross-border carbon markets. On the political side, there are likely to be certain expectations of some countries (e.g. developed countries with emissions reduction targets for 2020 should continue to have economy-wide emissions reduction targets in the future).

There are different ways in which bounded flexibility could be implemented. For example, one approach could be for Parties to agree on the time frame for commitments (e.g. all commitments are to be for the year 2030 or the period 2025-2030) and on the GWPs to be used for emissions accounting. It is possible that bounded flexibility could also be negotiated for other dimensions of mitigation commitments, depending on the varying national circumstances of countries. For some dimensions, countries could agree to transparency requirements if it is not possible to agree bounded flexibility. 
The ex-ante provision of information on the various dimensions of climate change commitments can improve understanding of the commitments put forward and provide a basis for tracking progress towards them. In particular, if all major emitters were to provide an estimated range for their future annual GHG emissions in a given year (e.g. 2030), this would facilitate estimation of the future global emissions pathway. In addition, further information would be needed to enhance understanding of how countries intend to meet their commitments. This could include information regarding domestic climate policies and sources of finance, as well as an explanation of why the commitments put forward are fair and ambitious given the circumstances of the country concerned.

The 2015 agreement and the post-2020 emissions accounting framework are likely to contain a combination of nationally-determined and internationally-agreed aspects. Nationally-determined elements are a prerequisite for the widespread participation of countries in the agreement. At the same time, internationally-agreed elements are needed to ensure that the overall agreement is fair and that the collective ambition of the commitments made is sufficient to meet the long-term global $2{ }^{\circ} \mathrm{C}$ goal. The key question for debate is not therefore whether the 2015 agreement should be "bottom up" or "top down"; it is which aspects of the new agreement should be nationally-determined, which aspects should be internationally-agreed, and what the role of the international negotiations is in both cases.

Time is short for countries to propose and negotiate commitments before 2015. An international process for establishing and understanding post-2020 commitments could consist of multiple stages. Figure ES.2 outlines possible stages. While commitments could be included in the agreement in some form at the end of 2015, work on increasing (or "ratcheting-up") the level of ambition of commitments through consultation and negotiation could continue beyond 2015.

Figure ES.2: A possible process with multiple stages

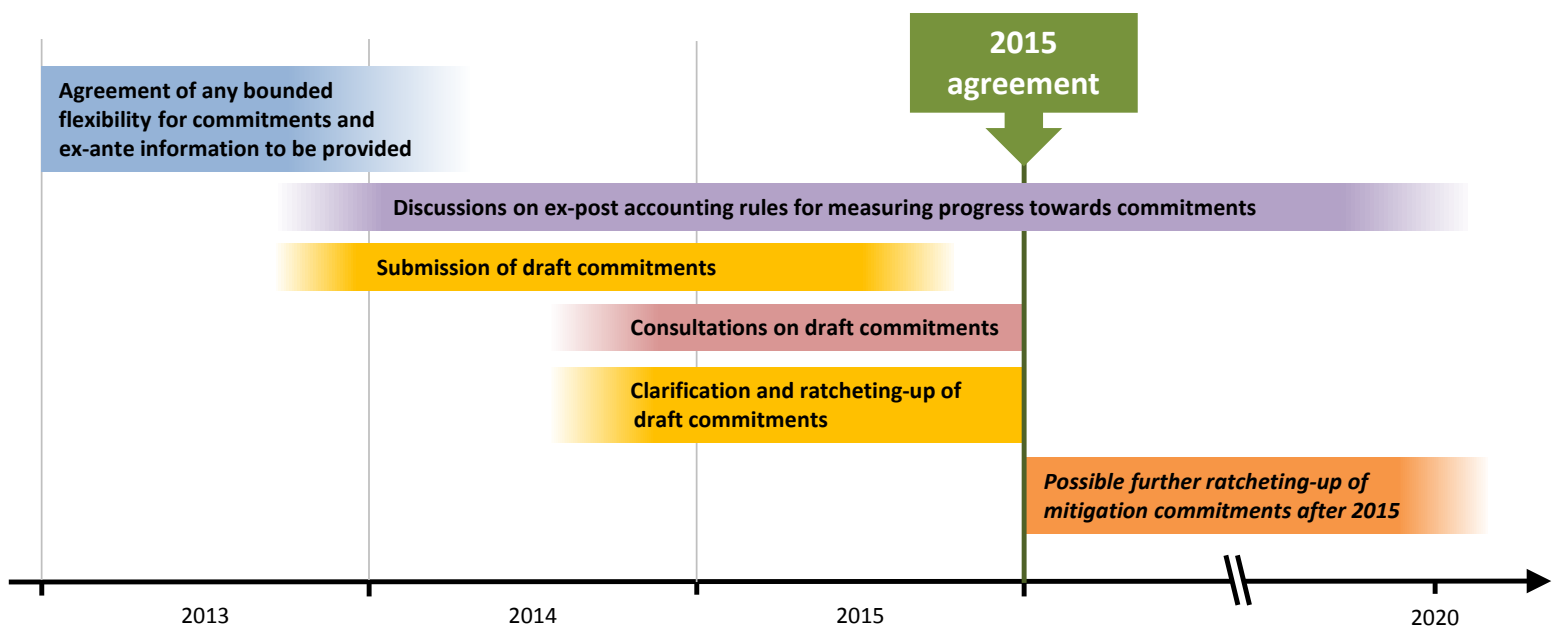

A key issue to be addressed is how to ensure that future nationally-determined commitments are collectively ambitious enough to put global emissions on a trajectory consistent with the $2{ }^{\circ} \mathrm{C}$ goal. International consultations on draft commitments could encourage governments to put forward ambitious draft commitments and subsequently raise the level of these draft commitments before they are included in the 2015 agreement. What the atmosphere "sees" are cumulative emissions; therefore less ambitious commitments in the near-term mean that stronger action will be needed in the future. The agreement could establish such a connection between subsequent rounds of commitments. Finally, in addition to enhanced action at the international level, a groundswell of action at the national and sub-national levels together with a shift in investment patterns from high-carbon to low-carbon activities will be needed to keep the $2{ }^{\circ} \mathrm{C}$ goal within reach. 


\section{Introduction}

The Earth's climate system is entering uncharted waters. In June 2013, the atmospheric concentration of $\mathrm{CO}_{2}$ exceeded $400 \mathrm{ppm}$ for the first time in at least the past 800,000 years. In order to avoid large and potentially irreversible changes to our climate system, anthropogenic emissions of greenhouse gas (GHG) emissions should peak soon and decline steeply thereafter (IPCC, 2013). Due to the long atmospheric lifetime of some GHGs such as $\mathrm{CO}_{2}$, the actions taken in the coming decades could have impacts on the state of the climate system for centuries to come. Further, early action on climate change is likely to be significantly more cost-effective than delayed action (OECD, 2012).

Climate change is one of a set of inter-linked environmental, economic and social challenges we are currently facing. It has the potential to exacerbate other threats to our economic well-being, such as biodiversity loss, diminishing access to freshwater, degradation of agricultural land and growing risks of resource-related conflicts. Action on climate change will therefore be an important component of the broader post-2015 political agenda, alongside other processes such as the Rio Conventions on biodiversity and desertification and the forthcoming Sustainable Development Goals.

It is against this backdrop that a new international climate change agreement is currently being negotiated under the auspices of the United Nations Framework Convention on Climate Change (UNFCCC). These negotiations aim to produce a balanced package of measures on mitigation, adaptation, finance, technology, capacity building and transparency that catalyse the transformation to low-carbon and climate-resilient economies. The new agreement is to be applicable to all countries, to have "legal force" and to be in accordance with the principles of the Convention. It is to be adopted by 2015 and to come into effect from 2020.

The commitments or contributions ${ }^{2}$ made under the 2015 agreement are likely to be nationallydetermined, reflecting the fact that all countries are sovereign states with different capacities and their own unique set of evolving national circumstances. At the same time, internationally-agreed guidance could help to ensure that the agreement is perceived to be fair and that the aggregate level of ambition of the agreement is consistent with the $2{ }^{\circ} \mathrm{C}$ goal agreed by all countries in $2011 .{ }^{3} \mathrm{~A}$ balance is needed: the 2015 agreement needs to be flexible enough to facilitate broad participation, but robust enough to ensure that the collective level of ambition of commitments made is sufficient to put us on a pathway to the $2{ }^{\circ} \mathrm{C}$ goal.

An emissions accounting system will be needed that facilitates tracking of progress towards individual country commitments as well as the long-term global goal. The emissions accounting system can be split into two components. The first is the ex-ante (i.e. before the start date of the commitment) component, which includes clarification of commitments and their expected GHG impacts. The second is the ex-post (i.e. after the start date of the commitment) component, which includes measurement, reporting and verification (MRV) of information on GHG emissions levels and other metrics used to measure progress towards commitments, as well as information on flows of units from market mechanisms and land-use emissions and sinks. An effective emissions accounting system would help to build trust between countries in the international negotiations. It could also help domestic climate legislation proponents to make the case for more ambitious policies in national

\footnotetext{
${ }^{2}$ Various terms have been used in this context by different countries, including “commitments”, “contributions”, "offers", "targets” and “actions”. The term "commitment” is used in this paper.

${ }^{3}$ At COP 16, countries agreed to limit the increase in global average temperature to below $2{ }^{\circ} \mathrm{C}$ above preindustrial levels. They also agreed to review this long-term global goal and to consider strengthening it to $1.5^{\circ} \mathrm{C}$ (UNFCCC, 2011a).
} 
climate policy debates by providing evidence that other countries are taking strong action on climate change.

The aim of this paper is to explore what mitigation commitments put forward under the 2015 agreement might look like, what guidance might be needed regarding the type of commitments proposed, and what "rules of the game" would need to be agreed before draft commitments for the post-2020 period are put forward. ${ }^{4}$ Building on previous CCXG work on emissions accounting, in particular Prag et al. (2013), it outline some of the implications for emissions accounting of having a diverse range of commitment types. It also outlines a possible multi-stage process for establishing commitments for the 2015 agreement.

The success of any 2015 international agreement will depend on getting the incentives right. The agreement should encourage large emitters to reduce their emissions while also providing incentives for economies that are currently low emitters to remain so, even as their economies grow. An effective agreement would also (i) accelerate the scaling up of flows of climate finance to developing countries, and ensure that this finance is effective; (ii) facilitate adaptation to the unavoidable impacts of climate change; and (iii) encourage all countries to achieve transitions to low-carbon, climate-resilient economies.

This paper is structured as follows: Section 2 outlines the timeline to the 2015 agreement and different dimensions of climate commitments; Section 3 examines options for post-2020 commitments and looks in greater detail at the information that would be needed to facilitate emissions accounting; Section 4 identifies a possible multiple-component process for establishing post-2020 commitments; and Section 5 concludes.

\section{Background}

There is not much time remaining until the new climate change agreement is to be adopted. This section outlines the timeline to 2015 and the key dates of some relevant events and processes.

\subsection{The timeline to 2015}

As the Co-Chairs of the Ad hoc Working Group on the Durban Platform for Enhanced Action (ADP) ${ }^{5}$ have pointed out, half of the lifetime of the ADP will have passed by the end of COP 19 in Warsaw (UNFCCC, 2013a). A co-ordinated international push to raise the profile of climate change as an issue on the political agenda in 2013-15 is necessary to secure an effective 2015 agreement. Ban Ki-Moon has already announced that he intends to convene world leaders in 2014 to mobilise political will on this issue. ${ }^{6}$ The OECD Secretary-General recently delivered a high-profile lecture calling for zero net emissions from fossil-fuels in the second half of this century (OECD, 2013). In addition to UNFCCC events, discussions in non-UNFCCC fora such as the G8, G20 and the Major Economies Forum on Energy and Climate (MEF) and elsewhere could help to build political momentum towards the 2015 agreement.

\footnotetext{
${ }^{4}$ The paper focuses on mitigation commitments, while recognising that commitments by developed countries to mobilise finance for mitigation and adaptation activities in developing countries could also play an important role in the 2015 agreement.

${ }^{5}$ The ADP is the UNFCCC body charged with delivering the 2015 agreement.

${ }^{6}$ This meeting of heads of state will probably take place on the fringe of the UN General Assembly in autumn 2014.
} 
An effective process for agreeing commitments for the 2015 agreement would take into account the timelines of existing UN processes, such as the publication of the fifth assessment report from the Intergovernmental Panel on Climate Change (IPCC) and the cycles of the MRV system under the Convention. Figure 1 outlines selected key dates and events for the international climate change negotiations in the period 2013-15. The figure also includes key dates for general elections in selected countries, as changes of government can have a profound impact on countries' negotiating positions within the UNFCCC. 
Figure 1. Timeline of selected key dates and events, 2013-15 (not comprehensive)

\begin{tabular}{|c|c|c|c|c|c|}
\hline & & UNFCCC events & & -UNFCCC events & General \\
\hline & Jan & & & & \\
\hline & Feb & & & & Italy \\
\hline & Mar & & & & \\
\hline & Apr & ADP 2, Bonn & MEF & MEF meeting, Washington DC & \\
\hline & May & & & & \\
\hline & Jun & ADP/SBI/SBSTA, Bonn & G8 & G8 Summit, UK & Iran \\
\hline & Jul & & MEF & MEF meeting, Krakow & Japan \\
\hline ○ & Aug & & & & \\
\hline & & & G20 & G20 Summit, St Petersburg & \\
\hline & Sen & & UN & UN General Assembly & Norway \\
\hline & & & MEF & MEF meeting, New York & Germany \\
\hline & & & IPCC & AR5 Working Group I report & \\
\hline & Oct & & & & \\
\hline & Nov & COP 19, Poland & & & Chile \\
\hline & Dec & & & & \\
\hline & Jan & NC6s and BR1s due (Al) & & & \\
\hline & Feb & & C40 & C40 Mayors Climate Summit & \\
\hline & Mar & & IPCC & AR5 Working Group II report & \\
\hline & & 1st round of $10 \mathrm{P}(\mathrm{Al}) *$ & IPCC & AR5 Working Group III report & South Africa \\
\hline & API & क & MEF & MEF meeting* & Indonesia \\
\hline & May & & & & India \\
\hline & Jun & ADP/SBI/SBSTA & G8 & G8 Summit, Russia & \\
\hline ○ & Jul & & & & \\
\hline & Aug & & & & \\
\hline & Sen & & UN & UN General Assembly & Suendon \\
\hline & sep & & MEF & MEF meeting* & sweden \\
\hline & Oct & & IPCC & AR5 Synthesis Report & Brazil \\
\hline & Nov & Pre-COP, Venezuela & G20 & G20 Summit, Australia & US \\
\hline & & COP 20, Peru & & & \\
\hline & Dee & BUR1s due (NAI) & & & \\
\hline & Jan & & & & \\
\hline & Feb & & & & \\
\hline & Mar & & & & \\
\hline & Apr & & MEF & MEF meeting* & \\
\hline & May & & & & UK \\
\hline & Jun & ADP/SBI/SBSTA & G8 & G8 Summit* & \\
\hline$\stackrel{\text { }}{~}$ & Jul & & & & Mexico \\
\hline & Aug & 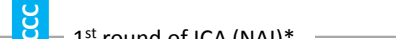 & & & \\
\hline & Sep & 1. TOUTI OT ICA (INAI) & MEF & MEF meeting* & Denmark \\
\hline & Oct & & G20 & G20 Summit, Turkey* & $\begin{array}{l}\text { Canada } \\
\text { Poland }\end{array}$ \\
\hline & Nov & & & & \\
\hline & Dec & COP 21, France & & & \\
\hline
\end{tabular}

* Precise dates to be confirmed.

Note: The 2013-15 review of the long-term global goal will be on-going throughout 2013-15. NC = national communication; $\mathrm{BR}=$ biennial report, $\mathrm{BUR}=$ biennial update report; $\mathrm{IAR}=$ international assessment and review; ICA = international consultations and analysis. 


\subsection{Existing pledges and different possible commitment types}

A starting point for looking at how commitments might fit together in the 2015 agreement is to look at existing pledges that countries have already put forward for 2020. Whilst the existing pledges should not be seen as indicators of what specific countries may choose to put forward for the period after 2020, they nonetheless provide an insight into the types of commitments that might generally be considered by governments.

At COP 16 in Cancun, Parties agreed to take note of the mitigation targets and actions submitted by countries. By May 2013, pledges had been submitted by all Annex I Parties (except Turkey) and 57 non-Annex I Parties, as well as the African Group (UNFCCC, 2011b; 2013b). Together these countries accounted for over $80 \%$ of global GHG emissions in 2010. No guidance was provided regarding the form of pledges to be put forward, other than that developed countries were to submit "quantified economy-wide emission reduction targets" and developing countries were to submit "nationally appropriate mitigation actions". Consequently, various quantitative and qualitative pledges were submitted (many of them for 2020), reflecting the different national circumstances of countries.

The expression of the headline number of a quantitative commitment has two parts, as demonstrated by the existing pledges: (i) the metric used, and (ii) the method of measurement used, which can be relative to a fixed level (e.g. the level of the metric in a base year) or relative to a business-as-usual (BAU) level. Table 1 outlines some of the different possible types of mitigation commitment ${ }^{7}$ and examples of existing pledges where available.

Table 1. Different commitment types and examples of existing pledges

\begin{tabular}{|l|l|l|}
\cline { 2 - 3 } \multicolumn{1}{c|}{} & $\begin{array}{l}\text { Relative to a fixed level (e.g. level } \\
\text { in a base year) }\end{array}$ & Relative to BAU level \\
\hline Annual GHG emissions & $\begin{array}{l}\text { EU's pledge to reduce GHG } \\
\text { emissions by 20-30\% by 2020 from } \\
1990 \text { levels. }\end{array}$ & $\begin{array}{l}\text { Brazil's pledge to reduce GHG } \\
\text { emissions by 36-39\% by 2020 } \\
\text { compared to BAU. }\end{array}$ \\
\hline Carbon neutrality & $\begin{array}{l}\text { Costa Rica's long-term pledge to } \\
\text { become carbon neutral. }\end{array}$ & Not applicable. \\
\hline $\begin{array}{l}\text { GHG emissions per unit } \\
\text { GDP }\end{array}$ & $\begin{array}{l}\text { China's pledge to reduce CO } 2 \\
\text { emissions per unit GDP by 40-45\% } \\
\text { by 2020 from 2005 levels. }\end{array}$ & $\begin{array}{l}\text { No pledges of this type submitted } \\
\text { to date (but could be in future). }\end{array}$ \\
\hline $\begin{array}{l}\text { Other quantitative metrics } \\
\text { non-GHG metrics) }\end{array}$ & $\begin{array}{l}\text { Tunisia's pledge to increase forest } \\
\text { cover from 12.8\% in 2009 to 16\% } \\
\text { by 2020; Ghana's pledge to increase } \\
\text { the share of renewables in the total } \\
\text { energy mix to 10-20\% by 2020; } \\
\text { Colombia's pledge to increase the } \\
\text { share of biofuels in national fuel } \\
\text { consumption to 20\% by 2020. }\end{array}$ & $\begin{array}{l}\text { No pledges of this type submitted } \\
\text { to date (but could be in future). }\end{array}$ \\
\hline
\end{tabular}

The commitment types in the first three rows above are expressed in terms of a GHG-related metric. The bottom row encompasses a range of different quantitative actions that could be expressed in terms

\footnotetext{
${ }^{7}$ Other types of useful mitigation commitment exist that are not captured in Table 1, such as the development of specific projects or the preparation of a low carbon development strategy.
} 
of various GHG-related metrics (e.g. GHG emissions per capita, cumulative GHG emissions) or nonGHG metrics that could have an impact on GHG emissions levels (e.g. forest cover, share of renewable energy). In some cases, the use of non-GHG metrics could encourage countries to put forward more ambitious commitments than if commitments were expressed in terms of GHGs alone. This is because non-GHG metrics can help place the focus on outcomes with clear domestic benefits and domains over which the government has greater control (e.g. cleaner energy, more forested areas), unlike metrics such as total GHG emissions that are also impacted by global macroeconomic trends and weather conditions.

Some countries have submitted more than one type of pledge. For example, in addition to its pledge to reduce its $\mathrm{CO}_{2}$ emissions per unit of GDP, China pledged to increase the share of non-fossil fuels in primary energy consumption to around $15 \%$ by 2020 and to increase forest coverage and forest stock by 40 million ha and 1.3 billion $\mathrm{m}^{3}$ respectively by 2020 compared with 2005 levels. In these cases, there may be reinforcing interactions between the multiple pledges. In the case of China, for example, achievement of the non-fossil fuel target could facilitate achievement of the intensity pledge (Zhang and Bauer, 2013). Some countries have non-GHG targets enshrined in domestic law, in addition to economy-wide GHG targets put forward under the UNFCCC. The EU, for example, has targets for renewable energy and energy efficiency that are legally-binding under EU law but not part of the UNFCCC process. These targets, if met, could however deliver greater emissions reductions than the GHG target (Sterk et al., 2013).

Figure 2 provides a summary of the existing pledges made and the pledge types used. It shows how most $^{8}$ of the largest GHG emitters had submitted a mitigation pledge for 2020 as of May 2013. Developed countries submitted pledges expressed as reductions in annual GHG emissions from a base year. Of the developing countries that submitted pledges, large emitters generally expressed their pledges in terms of a reduction in annual emissions from BAU levels or a reduction in GHG emissions per unit GDP relative to a base year. Small emitters generally expressed their pledges in terms of carbon neutrality or other quantitative goals, although there were exceptions in both cases.

\footnotetext{
${ }^{8}$ Of the twenty largest emitters in 2010, only Iran, Saudi Arabia and Thailand had not submitted a mitigation pledge for 2020 as of October 2013.
} 
Figure 2. Summary of 2020 pledge types

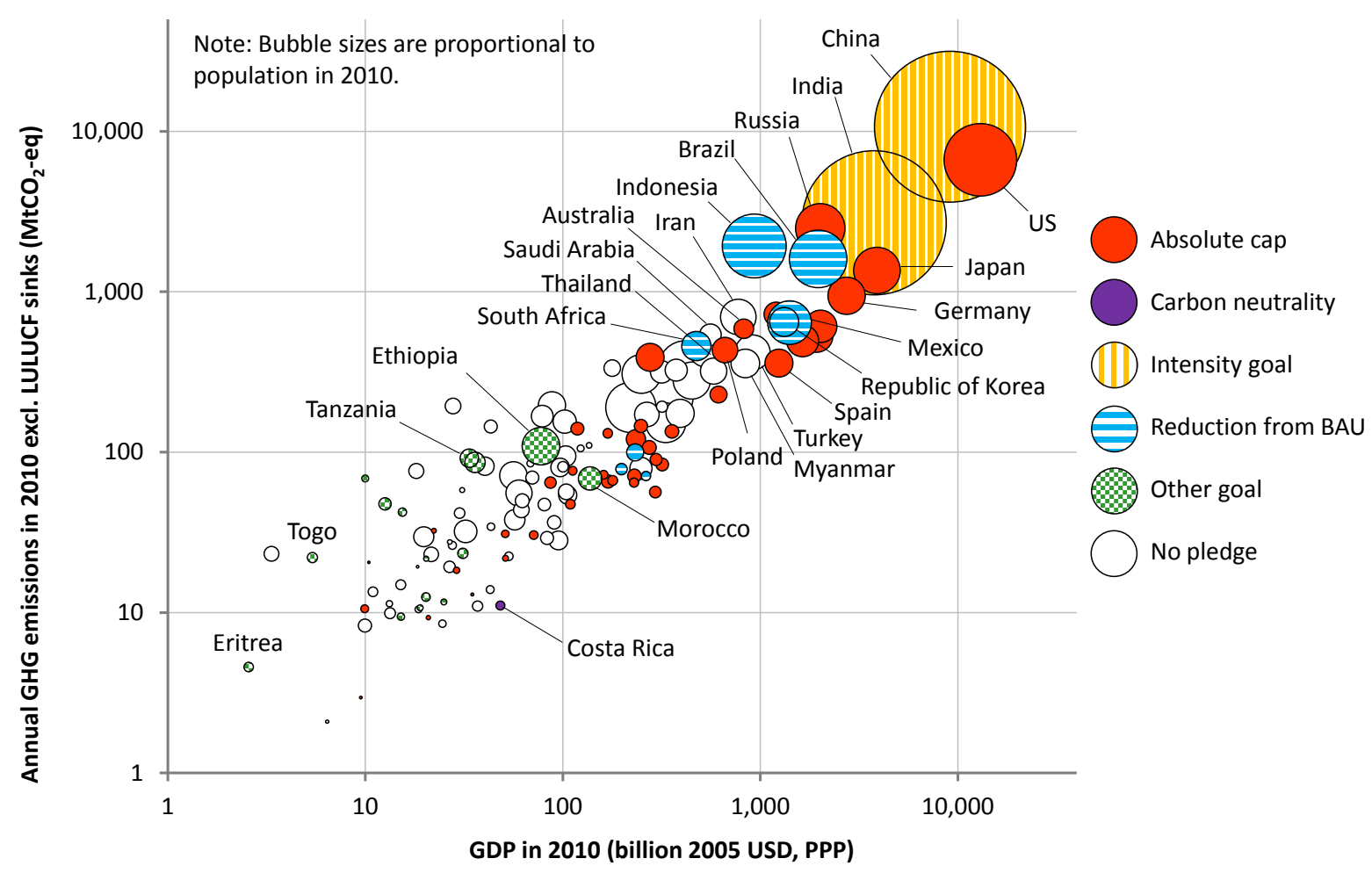

Source: Based on submissions from Parties under the Cancun Agreements (UNFCCC, 2011b; 2013b), GHG and GDP data from IEA (2012), and population data from UNDESA (2011

All commitment types have advantages and disadvantages. Table 2 provides a summary of some of these, based on earlier CCXG work (Philibert, 2005a; 2005b). Note that the stringency or level of ambition is not an inherent property of any single commitment type. Any type of commitment can be ambitious, and there is no reason why an intensity goal or a commitment relative to BAU cannot be equally or more ambitious than an absolute emissions reduction target. However, intensity goals and commitments expressed relative to BAU may have greater informational and MRV requirements than annual emissions reduction targets. In addition to the quantitative commitment types included in Table 2 , countries could also express other types of commitments with potentially significant impacts on GHG emissions, such as commitments to introduce carbon pricing, phase out fossil fuel subsidies or otherwise reform energy sector regulatory frameworks. 
Table 2. Advantages and disadvantages of different commitment types

\begin{tabular}{|c|c|c|}
\hline Commitment type & Advantages & Disadvantages \\
\hline $\begin{array}{l}\text { Economy-wide annual GHG } \\
\text { emissions, relative to a base year }\end{array}$ & $\begin{array}{l}\text { - High confidence regarding future } \\
\text { emissions levels (if commitments } \\
\text { are met) } \\
\text { - Simplifies emissions trading }\end{array}$ & $\begin{array}{l}\text { - Does not take into account } \\
\text { changing economic conditions }\end{array}$ \\
\hline $\begin{array}{l}\text { Economy-wide annual GHG } \\
\text { emissions, relative to a BAU } \\
\text { baseline }\end{array}$ & $\begin{array}{l}\text { - Can facilitate participation of } \\
\text { developing countries } \\
\text { - Can be a first step towards other } \\
\text { commitment types }\end{array}$ & $\begin{array}{l}\text { - Low confidence regarding future } \\
\text { emissions levels } \\
\text { - May complicate emissions } \\
\text { trading } \\
\text { - Can have lower transparency } \\
\text { - May complicate MRV } \\
\end{array}$ \\
\hline $\begin{array}{l}\text { Annual GHG emissions per unit } \\
\text { GDP, relative to a base year }\end{array}$ & $\begin{array}{l}\text { - Takes into account changing } \\
\text { economic conditions }\end{array}$ & $\begin{array}{l}\text { - Low confidence regarding future } \\
\text { emissions levels } \\
\text { - May lead to higher than expected } \\
\text { emissions if economic growth is } \\
\text { strong } \\
\text { - May complicate emissions } \\
\text { trading }\end{array}$ \\
\hline $\begin{array}{l}\text { Annual GHG emissions from one } \\
\text { or multiple sectors, relative to a } \\
\text { base year }\end{array}$ & $\begin{array}{l}\text { - High confidence regarding future } \\
\text { emissions levels from covered } \\
\text { sectors (but not uncovered sectors) } \\
\text { - Simplifies emissions trading }\end{array}$ & $\begin{array}{l}\text { - Possibility of inter-sector } \\
\text { leakage, if production shifts to an } \\
\text { uncovered sector } \\
\text { - Does not address all emissions } \\
\text { from an economy } \\
\end{array}$ \\
\hline $\begin{array}{l}\text { Commitments expressed in terms } \\
\text { of non-GHG metrics }\end{array}$ & $\begin{array}{l}\text { - Can facilitate participation of } \\
\text { developing countries } \\
\text { - Can focus on co-benefits and parts } \\
\text { of the economy over which } \\
\text { government has greater control }\end{array}$ & $\begin{array}{l}\text { - Low confidence regarding future } \\
\text { emissions levels } \\
\text { - May complicate emissions } \\
\text { trading }\end{array}$ \\
\hline
\end{tabular}

Source: Based on Philibert (2005a; 2005b)

Although there has been broad participation in submitting mitigation pledges under the Cancun Agreements, many of the pledges put forward lack the information needed to understand their expected impacts on GHG emissions (UNFCCC, 2013c). In particular, in the case of economy-wide pledges it is often not clear if or how units from international market mechanisms will be used, or how emissions and removals from forests and land use change will be treated. A series of UNFCCC workshops in 2012 had the objective of clarifying the pledges that had been made and the assumptions behind them. These workshops improved understanding of the pledges but large uncertainties remain regarding the aggregate impact that the pledges will have on individual emissions pathways as well as global GHG emissions levels in 2020 (UNEP, 2012).

\subsection{The multiple dimensions of mitigation commitments}

Climate change commitments can have multiple dimensions. The ambition of a commitment depends on all of these dimensions, as well as the national circumstances of the country concerned. For example, mitigation potential and abatement costs can vary significantly between countries, and this makes it difficult to compare the level of effort associated with different countries' commitments even if the other dimensions of the commitments are similar. Nevertheless, before considering an emissions accounting framework for commitments, it is first helpful to identify what the multiple dimensions of commitments are. 
The multiple dimensions of climate change mitigation commitments can include:

- Headline number: The headline number can be a percentage reduction (e.g. -20\%) or a specific figure (e.g. $700 \mathrm{MtCO}_{2}$-eq, $500 \mathrm{MW}$ installed capacity of renewable energy, 200,000 $\mathrm{km}^{2}$ of forest area).

- Metric: Metrics used to express commitment types can include those used for the existing pledges under the Cancun Agreements as well as alternative metrics that have not been used for pledges under the Cancun Agreements to date (e.g. cumulative GHG emissions, GHG emissions per capita, GHG emissions per unit energy, GHG emissions per kWh of electricity, GHG emissions per unit Human Development Index, energy consumption per unit floor area, investment in low carbon R\&D).

- Base year or BAU emissions (depending on commitment type): Commitments can be made with respect to the historical level of the metric concerned in a base year (e.g. 1990) or with respect to the BAU level.

- Time frame: Commitments can be made for a single year (e.g. 2030) or for a multi-year period (e.g. 2020-2030).

- Global Warming Potentials (or other GHG-equivalence metrics): Since the impact of different GHGs on the atmosphere varies depending on their physical and chemical properties, a method is needed for comparing emissions of different gases. Global Warming Potentials (GWPs) provide one way of doing this, by comparing the impact of the gas concerned with that of a reference gas (conventionally $\mathrm{CO}_{2}$ ) over a time horizon (e.g. 100 years). While acknowledging that other approaches are possible (e.g. the Global Temperature Potential [GTP] metric), the IPCC refers to GWPs as "the recommended metric to compare future climate impacts of emissions of long-lived climate gases” (IPCC, 2007b). Estimates of GWP values are provided in the IPCC assessment reports.

- Coverage of gases: Coverage can include one or more of the Kyoto basket of GHGs $\left(\mathrm{CO}_{2}\right.$, $\left.\mathrm{CH}_{4}, \mathrm{~N}_{2} \mathrm{O}, \mathrm{HFCs}, \mathrm{PFCs}, \mathrm{SF}_{6}, \mathrm{NF}_{3}\right)^{9}$ as well as other climate forcers (e.g. black carbon, tropospheric ozone).

- Coverage of sectors: Commitments can range from economy-wide to covering one sector only (e.g. energy, forestry, agriculture) or part of a sector (e.g. installation of a wind farm or hydroelectric power station).

- Approach used for land use accounting (if covered): A specific case of sectoral coverage. GHG sequestration or emissions from land use, land use change and forestry (LULUCF) can be an important component of the emissions inventory for some countries. Several different approaches for accounting for LULUCF emissions and sinks are possible.

- Source of finance: For some countries, the commitments could be funded wholly by domestic sources. For some developing countries, the commitments could be funded by international climate finance flows, or by a blend of domestic finance and international support. Some of the pledges put forward by developing countries under the Cancun Agreements are conditional on provision of finance (UNFCCC, 2013b).

- Conditions attached to commitments (if any): Conditions can relate to the commitments taken on by other countries, the collective level of ambition of the global agreement,

\footnotetext{
${ }^{9} \mathrm{NF}_{3}$ was added to the Kyoto basket of GHGs as part of the Doha Amendment to the Kyoto Protocol in December 2012.
} 
assumptions regarding the provision of financial support for actions in developing countries, the accounting rules to be used (most notably for LULUCF), or other aspects. Several developed and developing countries have put conditions on their pledges under the Cancun Agreements (UNFCCC, 2011b’2013b).

- Role of GHG units from market mechanisms: Some countries may choose to use GHG units from international market mechanisms or domestic crediting mechanisms to count directly towards meeting part of their commitments. Clarity on the types of units and maximum permitted flows is important.

Figure 3 shows one way of illustrating some of the multiple dimensions of commitments. Each dimension is assigned an axis. Different commitments will create different shapes, and differences between multiple commitments can be quickly identified. Two hypothetical commitments are depicted in Figure 3. For some dimensions, Commitment $\mathrm{A}$ may be considered more ambitious than Commitment B (e.g. Commitment A has a larger headline number), while for other dimensions Commitment B may be considered more ambitious than Commitment A (e.g. Commitment B has a broader coverage of sectors). Some dimensions are difficult to depict on a graphical axis (e.g. conditions attached) and have been omitted from the diagram. In general, the greater the area of the shape, the greater the level of ambition of the commitment - everything else being equal. However, a direct comparison of effort between two commitments in different countries remains challenging because this will ultimately depend on the national circumstances of the countries concerned.

Figure 3.Some of the multiple dimensions of commitments: two hypothetical examples

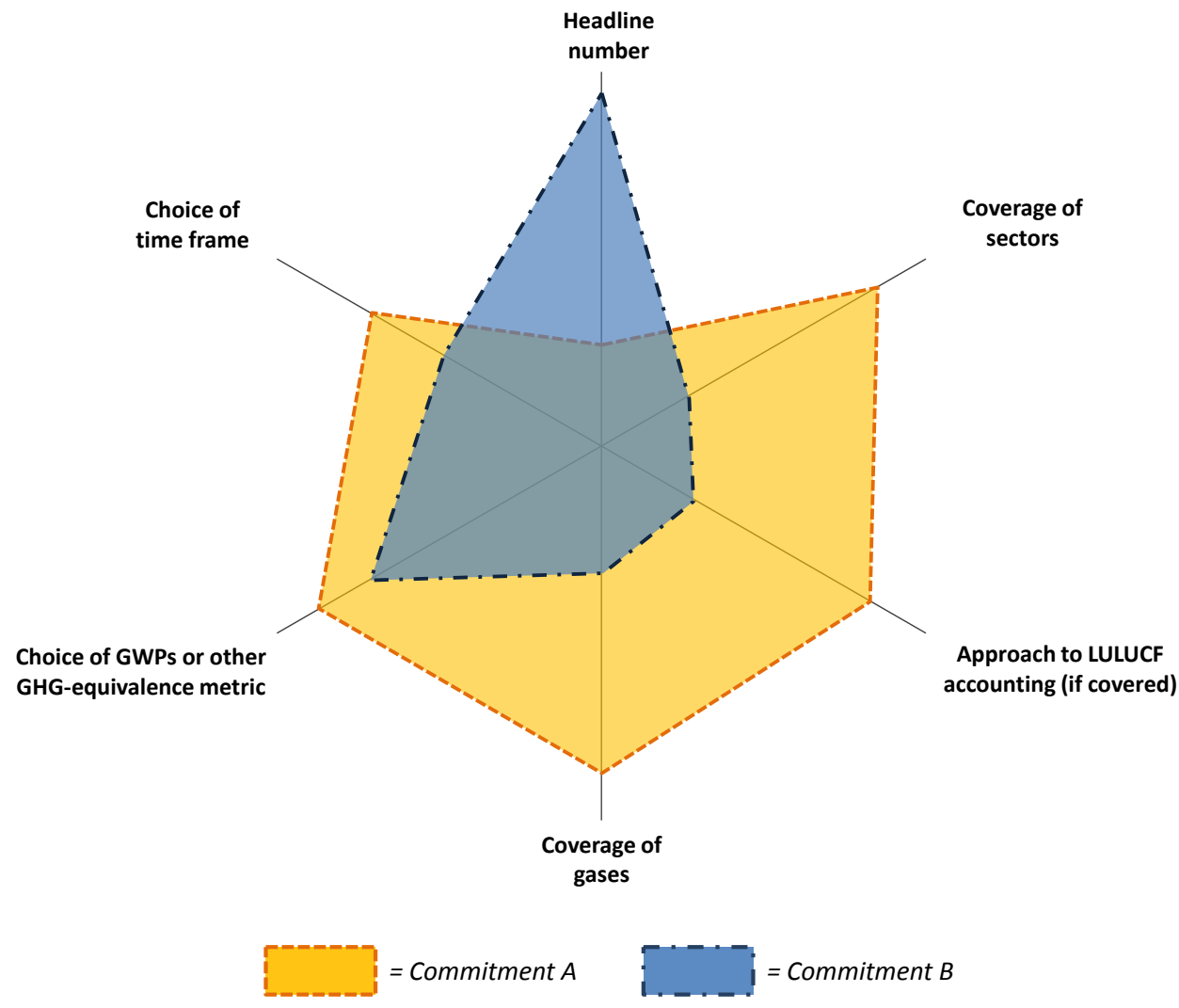




\section{Post-2020 mitigation commitments}

In order to provide a chance of meeting the $2{ }^{\circ} \mathrm{C}$ goal, the 2015 agreement should contain mitigation commitments from all major emitters. However, different types of commitment could be pursued by different countries, and this diverse range of post-2020 climate change commitments could present challenges for emissions accounting.

\subsection{Bounded flexibility for post-2020 commitments}

By explicitly agreeing the $2{ }^{\circ} \mathrm{C}$ long-term global goal, Parties to the UNFCCC have implicitly recognised the existence of a global GHG budget, although the precise size of this budget remains uncertain. One approach could be to divide this emissions budget between the Parties to the UNFCCC, taking into account the different national circumstances and starting points of different countries (either by negotiation or by the use of objective indicators). However, this "top-down" approach is challenging both at a political level (e.g. agreeing an "appropriate" start date) and at a technical level (e.g. given the limited availability of historical emissions data for current national boundaries). A second approach could be for countries to develop nationally-determined commitments with minimal international co-ordination, and with every country using its own metrics, time scales and accounting rules. This approach would make it challenging to estimate the future global emissions trajectory and to compare the progress being made towards individual commitments. ${ }^{10}$

A third, middle-ground approach could be for Parties to agree "bounded flexibility" ${ }^{11}$ for post-2020 commitments within the context of the UNFCCC. In this paper, bounded flexibility means that Parties could agree on the values or ranges of values to be used for some of the dimensions of mitigation commitments, while retaining flexibility for other aspects. The rationale for introducing bounded flexibility includes both technical and political arguments. Technical arguments include that having an internationally-agreed timeframe for commitments can make it easier to compare progress towards goals, reduce uncertainty associated with future emissions levels and simplify the operation of crossborder carbon markets. There may also be political expectations regarding the commitments put forward by certain countries (e.g. there could be expectations that developed countries with emissions reduction targets for 2020 should continue to have economy-wide emissions reduction targets in the future). Bounded flexibility would not necessarily ensure that the commitments put forward are ambitious (this would still ultimately depend on the level of political will to take strong action on climate change), but it could facilitate the comparison and assessment of commitments.

Bounded flexibility is not a new idea - it can already been seen in some UNFCCC provisions. For example, land use accounting under the Kyoto Protocol provides countries with some degree of flexibility regarding the activities they choose to include as sources and sinks of emissions from the land sector. Also, the MRV guidelines for reporting information on GHG inventories embody this concept (e.g. second national communications from non-Annex I countries shall contain a national GHG inventory for the year 2000, while other variables such as the timing of second national communications are not specified) (UNFCCC, 2002). Table 3 outlines possible options for bounded flexibility for post-2020 mitigation commitments. Note that the approach to bounded flexibility outlined in this paper in just one of many possible approaches.

\footnotetext{
${ }^{10}$ Comparing the progress made towards commitments is different to comparing the level of effort needed to meet commitments. The latter depends on specific domestic factors (e.g. abatement potential and costs) and is therefore difficult to compare regardless of the form in which commitments are expressed.
}

${ }^{11}$ At a MEF meeting in July 2013, participants “considered whether there should be any 'bounds' on the flexibility accorded to countries to come up with their nationally-determined commitments” (MEF, 2013). 
Table 3. Possible options for bounded flexibility for post-2020 commitments

\begin{tabular}{|c|c|}
\hline Dimension & Possible options for bounded flexibility \\
\hline $\begin{array}{l}\text { Commitment } \\
\text { type }\end{array}$ & $\begin{array}{l}\text { a) Commitments are to be clear and transparent } \\
\text { b) Commitments are to be quantitative } \\
\text { c) Developed countries are to take on economy-wide emissions reduction targets } \\
\text { d) Any type of commitment may be put forward }\end{array}$ \\
\hline Time frame & $\begin{array}{l}\text { a) Commitments are to be made for a single year (e.g. 2025, 2030, other) } \\
\text { b) Commitments are to be made for a multi-year period (e.g. 2021-2025, 2021-2030, } \\
\text { other) } \\
\text { c) Long and short-term commitments are to be made } \\
\text { d) Any time frame may be used }\end{array}$ \\
\hline Base year & $\begin{array}{l}\text { a) Commitments are to made relative to an agreed base year (e.g. 1990, 2000, 2005, 2010, } \\
\text { 2015, other), with countries choosing a different base year to provide a justification for } \\
\text { doing so } \\
\text { b) Commitments are to be made relative to an agreed historical time period (e.g. } 1990 \text { - } \\
1995,1990-2000,2000-2005 \text {, other), with countries using a different time period to } \\
\text { provide a justification for doing so } \\
\text { c) No agreed base year or time period for commitments, although countries are to provide } \\
\text { a justification their choice of base year or time period }\end{array}$ \\
\hline $\begin{array}{l}\text { GWP values } \\
\text { or other } \\
\text { GHG- } \\
\text { equivalence } \\
\text { metric }\end{array}$ & $\begin{array}{l}\text { a) Commitments are to use GWP values from IPCC [AR4] [AR5] } \\
\text { b) Commitments are to use GWP values from forthcoming IPCC reports, when available } \\
\text { c) Separate commitments can be made for different GHGs and not compared using GWPs } \\
\text { d) No agreed GWP values for commitments - countries are free to use any GHG- } \\
\text { equivalence metric they choose (e.g. GWPs, GTPs) }\end{array}$ \\
\hline $\begin{array}{l}\text { Coverage of } \\
\text { gases and } \\
\text { sectors }\end{array}$ & $\begin{array}{l}\text { a) Commitments are to cover, at a minimum, } \mathrm{CO}_{2} \\
\text { b) Commitments are to cover, at a minimum, } \mathrm{CO}_{2}, \mathrm{CH}_{4} \text { and } \mathrm{N}_{2} \mathrm{O} \\
\text { c) Commitments are to cover energy supply/transport/agriculture/forestry and land } \\
\text { use/industry/waste/any sector accounting for more than X\% of total GHG emissions } \\
\text { d) Any coverage may be used, although countries are to provide a justification of the } \\
\text { approach used }\end{array}$ \\
\hline LULUCF & $\begin{array}{l}\text { a) LULUCF sinks and emissions are to be excluded from commitments } \\
\text { b) International agreement on a single approach to LULUCF accounting } \\
\text { c) Agreement on general principles for LULUCF accounting } \\
\text { d) Any approach to LULUCF accounting may be used, although countries are to provide a } \\
\text { justification of the approach used }\end{array}$ \\
\hline Ranges & $\begin{array}{l}\text { a) Commitments are to be expressed using single values, not ranges of values } \\
\text { b) Commitments can be expressed as ranges }\end{array}$ \\
\hline Conditions & $\begin{array}{l}\text { a) Commitments are to be unconditional } \\
\text { b) Conditions may be attached to commitments }\end{array}$ \\
\hline $\begin{array}{l}\text { Use of units } \\
\text { from market } \\
\text { mechanisms } \\
\text { to meet } \\
\text { commitments }\end{array}$ & $\begin{array}{l}\text { a) Units may be used to meet up to [5\%][10\%][X\%] of commitments } \\
\text { b) No limit on quantity of units to be used to meet commitments }\end{array}$ \\
\hline
\end{tabular}




\section{Commitment type}

In general, it would help to facilitate emissions accounting and tracking of progress if mitigation commitments for the 2015 agreement were, to the greatest extent possible:

- Clear and transparent: What the draft commitment entails and the assumptions behind it need to be made transparent and understandable for all relevant stakeholders. At a meeting of the MEF in July 2013, the chair's summary noted "broad support for putting forward commitments with ex-ante clarity” (MEF, 2013). Current mitigation pledges for 2020 do not all meet this criteria (UNFCCC, 2013c).

- Quantified: Simply put, a quantified commitment contains one or more numerical objectives. This would facilitate the tracking of progress towards global goals and individual commitments. Ideally, the goals of major emitters would be quantifiable in terms of impact on emissions in order to facilitate scientific understanding of expected future GHG atmospheric concentrations. Quantification also facilitates the assessment of progress, which could be important for the possible legal form of commitments.

Furthermore, it would be desirable for commitments to be "future-proof". There will be a five-year interval between when the new agreement is expected to be agreed (by 2015) and when it is implemented (from 2020). Economic and social conditions could change significantly and unexpectedly in some regions during this time, as well as after 2020. Therefore the commitments for the 2015 agreement should be designed in such a way that they remain relevant in 2020 and beyond, i.e. they should be "future-proof". Note that a balance therefore needs to be struck between predictability and flexibility to update commitments to reflect changing external conditions.

The choices made by governments when drafting post-2020 mitigation commitments will have implications for the level of uncertainty associated with the future global emissions trajectory (and hence progress being made towards the $2{ }^{\circ} \mathrm{C}$ goal) as well as for the level of complexity of the post2020 accounting system. For example, the adoption of commitments expressed in terms other than annual or cumulative GHG emissions (e.g. intensity goals, commitments relative to BAU levels, use of non-GHG metrics) will increase the uncertainty associated with future emissions levels. Further, BAU baselines can cause challenges for emissions accounting due to their counter-factual nature (see Box $1)$. 


\section{Box 1: Challenges posed by BAU goals for emissions accounting}

Several non-Annex I countries have pledged to reduce or limit annual GHG emissions relative to BAU levels by 2020 (UNFCCC, 2013b). The advantage of expressing pledges in this way is that it enables governments to signal intent to mitigate GHG emissions without taking on an objective in terms of annual GHG emissions relative to a base year, which is commonly perceived as being more stringent and restrictive of economic growth. However, commitments expressed relative to BAU levels pose challenges for emissions accounting. In order to measure progress towards such commitments, it is necessary to have information on both the BAU baseline and actual emissions or performance. Since projected BAU baselines are hypothetical scenarios encapsulating a set of technical and political assumptions, they generally have a higher degree of uncertainty associated with them than fixed, measurable reference points such as total GHG emissions relative to a historical level or GHG emissions per unit GDP in a base year.

There is currently no internationally-agreed guidance for developing national emissions baselines. Consequently, a disparate set of approaches to developing BAU baselines has been used to date, with varying degrees of openness about the modelling approaches and assumptions used. Recent work assessing approaches to date and identifying elements of good practice suggests that transparency regarding the assumptions made in BAU scenarios is essential in order to understand them (DEA, OECD and UNEP Risø Centre, 2013; Clapp and Prag, 2012). If countries choose to continue to put forward goals relative to BAU for the post-2020 period, greater consistency in the approaches used by countries for baseline setting would help to make the commitments more comparable.

A further difference between commitments measured relative to a BAU baseline and those measured against a historical reference point is that BAU baselines can be revised over time as country circumstances change, even before the end of the commitment period. ${ }^{12}$ Countries have taken different approaches to revisions to date; for example, some countries with pledges relative to BAU have frozen the BAU baseline for the duration of the pledge (e.g. South Africa). Other countries have announced that their BAU baseline will be revised regularly (e.g. Mexico). Revisions of BAU baselines can change the stringency of commitments as well as the level of expected emissions, i.e. if a BAU baseline is revised upwards then the allowed level of annual emissions in the target year becomes higher, and vice versa. On the other hand, if BAU baselines are frozen they cannot reflect changes in external factors over time and become increasingly inaccurate portrayals of current understanding.

\section{Time frame}

A dimension for which bounded flexibility could be agreed is the time frame for commitments. Agreeing a single target year or period for post-2020 commitments (e.g. deciding that all commitments are to be for the year 2025, 2030, 2025-2030, etc.) would facilitate estimations of what future global GHG emissions could be in the chosen target year or period. Alternatively, Haites et al. (2013) propose that national commitments could cover a four-year period and be automatically followed by a more ambitious four-year commitment. Countries could also be encouraged to submit long-term commitments (e.g. for 2050) in addition to short-term commitments, in order to provide a clearer picture of the long-term global emissions pathway. Countries could be encouraged to undertake early

\footnotetext{
${ }^{12}$ While historical data sets on metrics such as GHG emissions and GDP can also be revised for technical reasons, the adjustments made are typically minor and the potential for political influence on the revision process is much lower than that for BAU baseline revisions.
} 
action rather than later action, since early action on climate change is likely to be more cost-effective in the long run (OECD, 2012).

The decision text of the Cancun Agreements invited countries to submit information on mitigation targets and actions that they intend to implement, but did not specify a time frame for these targets and actions. Consequently some countries submitted pledges for 2020 only; some submitted pledges for 2020 and also referred to longer-term goals in their submissions (e.g. the EU, US, Costa Rica, Mauritania, South Africa); some submitted long-term pledges only (e.g. Papua New Guinea, Togo); and many smaller emitters submitted qualitative pledges with no specified time period (e.g. Benin, Botswana, Georgia, Jordan, Madagascar, amongst others) (UNFCCC, 2011b; 2013b).

Setting commitments for a target period rather than a single target year could reduce uncertainty associated with future estimates of atmospheric GHG concentrations, since these depend on cumulative GHG emissions rather than annual emissions in any single year. It would also limit the impact of annual variability in the metric concerned (e.g. caused by unusually warm or cool temperatures, or unusually low or high rainfall in one year) on whether the commitment is achieved, which could be an issue for single year targets (see Figure 4). Commitments for cumulative emissions over a period could also simplify the issuance and use of GHG units from international market mechanisms to meet commitments, since GHG unit transactions could be undertaken throughout the multiple-year period rather than all at once in a single target year (for a fuller discussion of single versus multiple-year targets, see Prag et al., 2013).

Figure 4. Illustration of single year versus multiple-year period targets
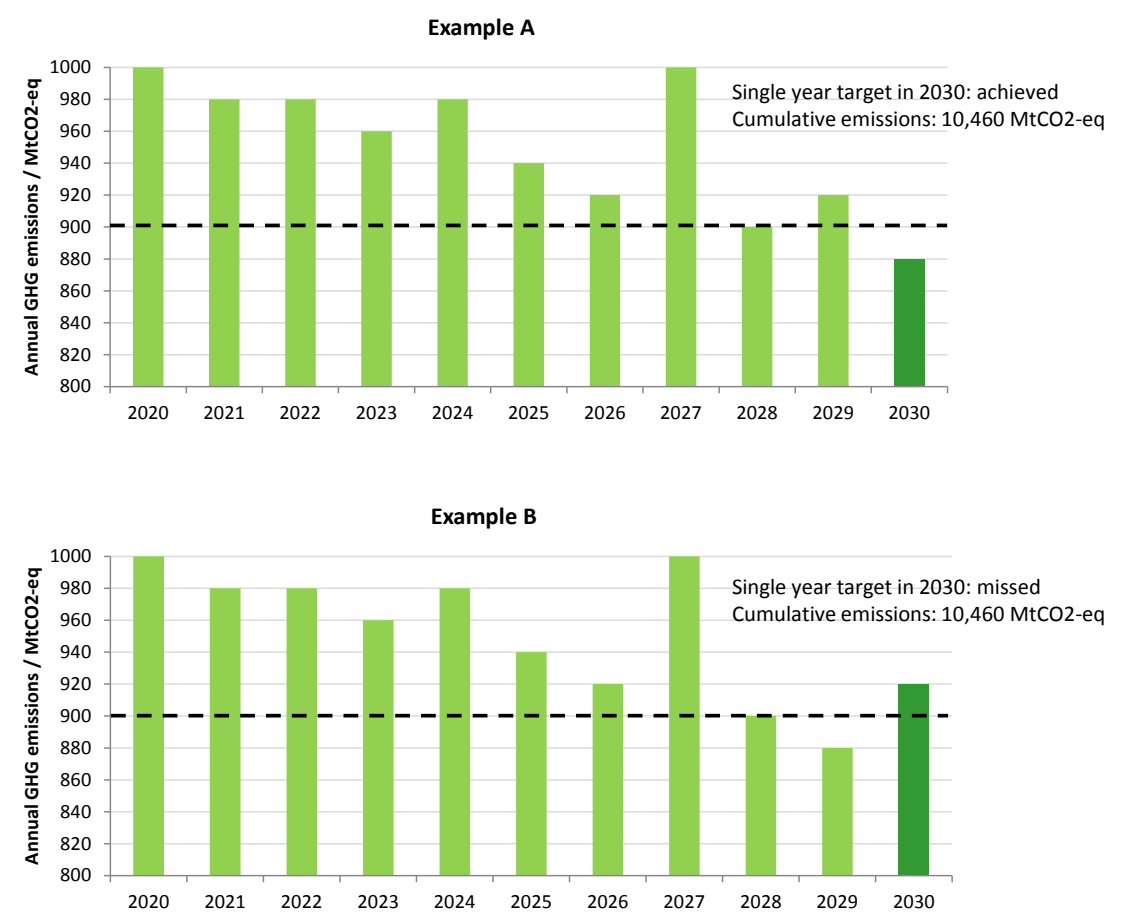

\section{Base year}

It is possible that the form of base year or period to be used for post-2020 commitments could be agreed, either in terms of a single year or a historical time period. The use of a historical base period as a reference point for commitments could help to mitigate the effect of years in which the metric in question was unusually high or low, as described above. However, given the diverse range of national 
circumstances that exist, it could be difficult to reach international agreement on what the base year or period for commitments should be. For example, base years used for pledges under the Cancun Agreements included 1990 (many countries), 2000 (Australia), 2005 (US, Canada, China, India, Central African Republic, Togo), 2009 (Marshall Islands, Mauritania, Tunisia) and 2010 (Gabon). Further, different base years might be used for different GHGs, since the time period for which historical emissions data is available can vary by gas.

The base year used can affect the level of ambition of a commitment, since if the metric concerned is unusually high in the base year then it may be easier to achieve apparent reductions in the metric over time, and vice versa. For commitments relative to BAU levels, the year used as the start year for the projection is also important because it can affect trend calculations over the time period of the baseline. As long as emissions (or other metric) in the base year are known, the use of different base years should not hamper the estimation of future global emissions levels or the measurement of progress towards commitments, although it can make it more complicated to compare effort.

\section{GWP values or other GHG-equivalence metrics}

Bounded flexibility could be agreed for the GHG-equivalence metric GWP values to be used by countries when accounting for multiple GHGs in their commitments. Existing guidelines for emissions inventories specify GWPs using $\mathrm{CO}_{2}$ as a reference gas and a 100-year time horizon. These GWP values are periodically updated by the IPCC to reflect the latest understanding of atmospheric chemistry processes and the climate impact of different GHGs. The changes in GWPs can be significant between IPCC reports; for example, the 100-year GWP of methane was estimated to be 21 in the second assessment report, 23 in the third assessment report and 25 in the fourth assessment report (IPCC, 2007a).

It would facilitate the emissions accounting process if all countries used the same GWPs when reporting emissions levels and progress made towards commitments. It is conceivable that countries could use a different GHG-equivalence metric when accounting for their commitments (e.g. GTPs), but this would make it more complicated to compare emissions totals across countries and estimate future global GHG emissions. Alternatively, separate commitments could be proposed for GHGs with different atmosphere residency times (without using GWPs to aggregate them), reflecting the different policy issues involved when addressing short and long-lived climate forcers.

\section{Coverage of sectors and gases}

Countries could agree that commitments are to cover, at a minimum, $\mathrm{CO}_{2}$ only, or $\mathrm{CO}_{2}, \mathrm{CH}_{4}$ and $\mathrm{N}_{2} \mathrm{O}$. This is because in most countries these gases form the majority of countries' GHG impact and better data is generally available on these gases in both developed and developing countries. Data availability is often more patchy for other GHGs, however, such as HFCs, PFCs, $\mathrm{SF}_{6}$ and $\mathrm{NF}_{3}$. It could, however, be politically difficult to agree limits on flexibility for the coverage of sectors, since countries can have very different emissions profiles and domestic policy priorities. The coverage of sectors may range from an economy-wide commitment for all sectors to a commitment for only one sector or sub-sector (e.g. the passenger vehicles sub-sector within the transport sector). It is important that key sources as well as sectors for which the likelihood of future increases in emissions is high (e.g. agriculture in some countries) be included.

There is a link between the coverage and the level of ambition of a commitment, since broadening the coverage of a commitment can increase its ambition. However, broader coverage does not always guarantee increased ambition. For example, if the coverage of a pledge is broadened to include sinks from the land use sector then the overall effect may be to decrease the amount of abatement required 
in other sectors (depending on the accounting approach used). For commitments that are not economywide, however, countries should provide information on sector definitions in order to clarify which installations and sources of emissions would be addressed by the commitment. In cases where a significant change to the coverage of a commitment is made, the level of the base year and the target level of emissions in the end year would need to be recalculated (WRI, 2013a).

\section{LULUCF accounting}

Emissions and sinks from the land-use sector play an important role in the emissions profile of many countries. However, there are often large uncertainties associated with estimates of LULUCF sources and sinks, and the accounting approach used can have a large impact on emissions levels. Excluding all emissions and sinks from this sector is perhaps the simplest option from an emissions accounting perspective. However, this would provide only part of the picture in terms of each country's impact on the atmosphere and is unlikely to be politically acceptable for countries with large GHG sinks.

The use of a common approach to land-use accounting would facilitate emissions accounting by making it easier to compare trends in LULUCF sources and sinks in different countries. However, reaching agreement on a single approach to LULUCF accounting would be challenging because this would have a heterogeneous impact on the stringency of different countries' commitments (for a fuller discussion see Prag et al. [2013]). Alternatively, a general set of principles for LULUCF accounting might be agreed. For example, countries could agree that forestry is to be accounted for, or that information on activities that are not emissions sources does not have to be reported. In the absence of an agreement on general principles for LULUCF accounting, countries could simply agree on transparency regarding the approach used.

\section{Commitments expressed as ranges with conditions attached}

Ranges and conditions increase the uncertainty associated with the future GHG global emissions trajectory. For example, analysis of the 2020 pledges by UNEP (2012) showed that ranges are a key source of uncertainty for GHG emissions levels in 2020 - a more significant factor than whether strict or lenient accounting rules are assumed.

A distinction can be drawn between ranges that are used to reflect uncertainty in the target level of emissions (or other metric), and ranges that are used to express the conditions attached to commitments. An example of the former is China's goal to reduce $\mathrm{CO}_{2}$ emissions per unit GDP by 40$45 \%$ by 2020 from 2005 levels. There is no difference in conditionality between the upper and lower bounds of the range; thus this implies that the goal is to reduce $\mathrm{CO}_{2}$ emissions per unit of GDP to somewhere between $40 \%$ and $45 \%$ below 2005 levels by 2020. An example of a range linked to conditions is Australia's pledge to reduce emissions in 2020 relative to 1990 levels by (i) $5 \%$ unilaterally; (ii) $15 \%$ with some conditions attached; or (iii) $25 \%$ with further conditions attached. ${ }^{13}$ There is a general expectation that conditions will need to be resolved at some point (e.g. an announcement made whether the final target is 5, 15 or $25 \%$ ).

In some cases the use of ranges with conditions attached may be needed for domestic political purposes - particularly conditions related to the actions of other countries. It could therefore be challenging to agree bounded flexibility for ranges and conditions. It would, however, be helpful in all cases for any ranges and conditions to be clearly stated, and for Parties to declare as soon as possible whether their conditions have been met.

\footnotetext{
${ }^{13}$ Note that the pledge is to reduce emissions by $5 \%$ or $15 \%$ or $25 \%$ - not by any value between $5 \%$ and $25 \%$.
} 


\subsection{Use of market mechanisms}

Many countries are likely to use international market mechanisms as a tool to decrease the cost of meeting their post-2020 mitigation commitments. Discussions of market-based approaches in the context of the UNFCCC are currently taking place along two parallel tracks: (i) the elaboration of a new market-based mechanism (NMM) under the guidance and authority of the COP; and (ii) the consideration of a framework for various approaches (FVA) that would facilitate recognition of units from non-UNFCCC market mechanisms. While the form and function of these mechanisms remain to be clearly defined, it is likely that international market mechanisms will continue to play a key role in the post-2020 period.

One of the possible roles of the NMM and FVA will be to ensure the environmental integrity (i.e. quality) of the units from market mechanisms used to meet UNFCCC commitments. In addition to this, countries could agree bounded flexibility for the quantity of units from market mechanisms used to meet commitments. The rationale for doing this would be to provide reassurance that countries intending to use international unit transfers will nevertheless take significant domestic action to reduce emissions.

In addition, bounded flexibility for the use of units flowing into a country could help to limit the risk of "double claiming" of units between countries. In some cases it may not be clear in advance whether units transferred internationally might be counted towards more than one country's commitment, and a "supplementarity" number for such units places an upper bound on this occurring. On the other hand, the introduction of a limit on use of some GHG units might reduce the cost-effectiveness of any future international market mechanism. Reaching agreement on the appropriate level of any such limit might therefore prove challenging. In order to facilitate ex-ante understanding of commitments, bounds on use of units could also be considered for commitments that are put forward for a single year only rather than a multi-year period (Prag et al., 2013).

\subsection{Ex-ante clarification of post-2020 commitments}

For some of the dimensions outlined above in Section 3.1, countries could agree to transparency or disclosure requirements if it is not possible to agree to bounded flexibility for those dimensions. For example, countries could agree that any commitments expressed relative to a BAU scenario should be accompanied by information on expected BAU emissions, or that commitments that are not economywide should provide information on sector definitions and coverage. This section looks in more detail at the ex-ante information needed to understand different types of commitments (regardless of whether bounded flexibility has been agreed) and how they might contribute to the overall global mitigation effort. This information would be helpful not only for Parties to the UNFCCC and international stakeholders, but also national government bodies (e.g. parliaments), sub-national governments, civil society and the business community.

Table 4 provides a summary of the ex-ante information needed to understand commitments. The table demonstrates that while some commitment types would need certain information (e.g. carbon neutrality goals should be accompanied by a definition of carbon neutrality), many of the items listed in the table are required regardless of the type of commitment. The principle aim of this information would be to enhance understanding of commitments; however, since the 2015 agreement is to have legal force, an open question remains regarding what would happen in the event of subsequent deviations from the ex-ante information provided (e.g. if discrepancies exist between expected and real values for future GHG emissions, costs and use of market mechanisms). 
Table 4. Summary of ex-ante information needed to understand commitments

\begin{tabular}{|c|c|c|c|c|c|}
\hline Information & $\begin{array}{l}\text { Reduction in } \\
\text { annual GHG } \\
\text { emissions } \\
\text { from a fixed } \\
\text { level }\end{array}$ & $\begin{array}{l}\text { Achievement } \\
\text { of “carbon } \\
\text { neutrality” }\end{array}$ & $\begin{array}{l}\text { Reduction in } \\
\text { GHG emissions } \\
\text { per unit GDP } \\
\text { from a fixed } \\
\text { level }\end{array}$ & $\begin{array}{l}\text { Reduction } \\
\text { in GHG } \\
\text { emissions } \\
\text { from BAU } \\
\text { level } \\
\end{array}$ & $\begin{array}{l}\text { Other } \\
\text { quantitative } \\
\text { mitigation } \\
\text { action }\end{array}$ \\
\hline Time frame & $\checkmark$ & $\checkmark$ & $\checkmark$ & $\checkmark$ & $\checkmark$ \\
\hline Base year & $\checkmark$ & $x$ & $\checkmark$ & $x$ & $(\sqrt{ }) *$ \\
\hline $\begin{array}{l}\text { GWP values or other } \\
\text { GHG-equivalence } \\
\text { metric }\end{array}$ & $\checkmark$ & $\checkmark$ & $\checkmark$ & $\checkmark$ & $(\checkmark) *$ \\
\hline Coverage of gases & $\checkmark$ & $\checkmark$ & $\checkmark$ & $\checkmark$ & $(\checkmark) *$ \\
\hline Coverage of sectors & $\checkmark$ & $\checkmark$ & $\checkmark$ & $\checkmark$ & $(\sqrt{ }) *$ \\
\hline LULUCF accounting & $\checkmark$ & $\checkmark$ & $\checkmark$ & $\checkmark$ & $(\sqrt{ }) *$ \\
\hline $\begin{array}{l}\text { BAU emissions and } \\
\text { baseline assumptions } \\
\text { (i.e. without action) }\end{array}$ & $x$ & $x$ & $x$ & $\checkmark$ & $x$ \\
\hline $\begin{array}{l}\text { Expected range of } \\
\text { future emissions (i.e. } \\
\text { with action) }\end{array}$ & $\checkmark$ & $\checkmark$ & $\checkmark$ & $\checkmark$ & $(\sqrt{ })^{*}$ \\
\hline GDP projections & $x$ & $x$ & $\checkmark$ & $x$ & $(\checkmark) *$ \\
\hline $\begin{array}{l}\text { Definition of carbon } \\
\text { neutrality }\end{array}$ & $x$ & $\checkmark$ & $x$ & $x$ & $x$ \\
\hline $\begin{array}{l}\text { Conditions attached } \\
\text { (including any relating } \\
\text { to finance and } \\
\text { increasing ambition } \\
\text { over time) }\end{array}$ & $\checkmark$ & $\checkmark$ & $\checkmark$ & $\checkmark$ & $\checkmark$ \\
\hline $\begin{array}{l}\text { Explanation of } \\
\text { ambition in light of } \\
\text { science and equity }\end{array}$ & $\checkmark$ & $\checkmark$ & $\checkmark$ & $\checkmark$ & $\checkmark$ \\
\hline Source of finance & $\checkmark / x *$ & $\checkmark$ & $\checkmark$ & $\checkmark$ & $\checkmark$ \\
\hline $\begin{array}{l}\text { Domestic legal status } \\
\text { and policies } \\
\text { planned/implemented }\end{array}$ & $\checkmark$ & $\checkmark$ & $\checkmark$ & $\checkmark$ & $\checkmark$ \\
\hline $\begin{array}{l}\text { Use of units from } \\
\text { market mechanisms }\end{array}$ & $\checkmark$ & $\checkmark$ & $\checkmark$ & $\checkmark$ & $(\sqrt{ })^{*}$ \\
\hline
\end{tabular}

*If applicable/available.

\section{Information needed to understand commitments and their expected GHG impacts}

For all commitment types, it is important that information be provided regarding the time frame (either a single year or multi-year period), which gases are included, the GWPs or other GHG-equivalence metric used to calculate emissions totals and the definitions of the sectors covered by the commitment (if they are different to those used for the national GHG inventory). For reductions in GHG emissions or other metric from a base year, the base year (either a single year or multi-year period) also needs to be stated, as well as the value of the metric concerned in that year. A base year is not required to understand a carbon neutrality goal or a commitment relative to BAU, although the start year used for emissions projections can be helpful for understanding a BAU baseline. 
It is important to know for all commitment types which categories of emissions and sinks from the land-use sector are included or excluded. If included, further information should be provided on the LULUCF accounting approach that will be taken (e.g. land-based or activity-based accounting), methodology that will be used to calculate LULUCF emissions and sinks (e.g. IPCC good practice guidance, Kyoto Protocol LULUCF accounting rules), and how natural disturbances and harvested wood products will be treated. ${ }^{14}$

For commitments relative to BAU, it would be important to know the expected BAU level of the metric concerned as well as the assumptions underpinning the baseline calculation (see the example of Brazil in Box 2). Information about whether the government intends to update the BAU scenario (and if so, how) should also be provided, as this can be important for estimating overall progress.

\section{Box 2: Brazil's BAU pledge for 2020 and climate change law}

In 2009, Brazil announced its intention to reduce national GHG emissions by 36.1-38.9\% relative to BAU levels. The subsequent domestic legal process highlights both how domestic legislation can back up an international commitment, as well as giving an example of how information concerning a BAU pledge has been made available.

The original submission to the Copenhagen Accord also included the emissions reductions expected from a small number of broad segments of the economy including reduced deforestation of different forest area types and other land-use change initiatives, improvements in energy efficiency, expansion of hydropower, biofuels and other renewable energy sources. In December 2010, a law was passed in Brazil that codified not only this reduction target but also the BAU baseline against which it will be measured (Government of Brazil, 2010).

An annex to the government decree describes how the BAU project was put together for various sectors. For deforestation, a simple average of deforestation rates in 1996-2005 was used, multiplied by emissions factors used in the Brazilian national inventory. For energy-related emissions, an emissions scenario was calculated including planned extensive developments of hydropower and other renewables, and avoided emissions from the hydropower were then added to the total (because the renewables developments were considered to be unlikely to have occurred under BAU conditions).

If all countries, regardless of commitment type, could provide expected ranges for their GHG emissions in a given future year (e.g. 2030), this would facilitate estimations of the future global GHG emissions pathway and collective progress towards the $2{ }^{\circ} \mathrm{C}$ goal. It is likely that the uncertainty associated with these estimates would be high due to heterogeneity amongst countries of data quality and sophistication of modelling approaches. Nevertheless, this data could provide a sense of the expected future global GHG emissions pathway and the collective potential impact of the commitments proposed. Ideally, the estimations of expected future emissions levels would be accompanied by information on the assumptions made.

Countries submitting commitments to become carbon neutral by a certain date should be clear on how they will define and account for the commitment because no internationally-agreed definition of national "carbon neutrality" yet exists. Under the Cancun Agreements, four countries submitted pledges to become or to remain carbon neutral (Bhutan, Costa Rica, the Maldives and Papua New Guinea). Further, during the 2020 pledge clarification process, Monaco and Norway expressed an intention to become carbon neutral over a longer time-period (UNFCCC, 2012). But exactly what

\footnotetext{
${ }^{14}$ For a fuller discussion of options for LULUCF accounting, see Prag et al. (2013).
} 
these commitments entail remains unclear. For example, how will developing countries intending to use land-use sinks to reach carbon neutrality ensure that annual net emissions are zero or less than zero each year? Will GHG units be purchased to bring annual net emissions down to zero every year?

For all commitment types, information may be provided on any conditions attached to the commitment. These could include conditions relating to the actions taken by other countries, the nature and level of ambition of the 2015 agreement, access to market mechanisms, or assumptions regarding sources of financing for actions taken in developing countries. It is possible that a range of mitigation options with differing levels of conditionality could be put forward. The conditions should leave open the possibility for the ambition of the commitment to be raised later on, should national circumstances present an opportunity to do so.

From an emissions accounting perspective, conditions attached to commitments represent an extra source of uncertainty for estimates of future global emissions levels. However, countries may need to strike a balance between reducing the uncertainty of future global emissions levels and retaining flexibility to change commitments later on with a view to maximising mitigation outcomes.

\section{Other information to improve understanding of commitments}

The information outlined above would help to improve understanding of different commitments and their expected impacts on future GHG emissions levels in governments, business and civil society. In addition, countries could put forward further information to help explain (i) why their commitments are ambitious with respect to science and equity, and (ii) how they intend to meet their commitments.

Countries could provide an explanation of why their commitment is ambitious given their national circumstances and capacity. Countries could choose to use nationally-determined indicators for this purpose, such as estimated emissions mitigation potentials and abatement costs if available, while recognising that different countries may use different indicators and the complex national circumstances of a country cannot be reduced to a single number. Further, countries could provide an explanation of how the expected impact of the commitment represents a fair share of the global mitigation effort required to put us on a pathway towards the $2{ }^{\circ} \mathrm{C}$ global goal, as outlined by the latest science from the IPCC.

Information could also be provided on how the country views its pledge as equitable, while recognising that different views exist of what terms such as "fair" and "equitable" mean in the context of climate change action. Equity can refer to the distribution of costs and benefits between countries, within countries or between generations. It can also touch upon issues of climate justice, rights and equitable access to sustainable development, vulnerability and gender inequalities (Mary Robinson Foundation, 2013; WRI, 2013b).

Developing countries could provide information on the expected sources of funding for their mitigation actions (non-Annex I countries are already encouraged to provide this information in national communications and biennial update reports). This clarification could help to further enhance understanding of how countries intend to meet their commitments and could also help to provide a rough estimate of the scale of the funding challenge for mitigation activities in developing countries in the post-2020 period.

Countries could choose to provide information on relevant international agreements taking place outside of the UNFCCC, either bilaterally or regionally, as well as action being taken or planned at the sub-national and city level. Although independent of the UNFCCC, these initiatives could be seen as part of countries' broader contribution to tackling climate change and provide a sign of political 
engagement on the issue. International initiatives of this type can include other UN processes such as the Montreal Protocol, the International Maritime Organisation (IMO), the International Civil Aviation Organisation (ICAO) and the Climate and Clean Air Coalition, as well as bilateral or plurilateral agreements in other political fora such as the G8, G20, the MEF and the World Trade Organisation (WTO).

One way governments can demonstrate that they remain committed to meeting their mitigation objectives is by passing laws and implementing policies that will help to achieve them. Existing reporting requirements for Annex I countries require them to detail the policies and actions being implemented domestically to achieve their actions, while non-Annex I countries are encouraged to do so. Countries could also demonstrate how short-term actions are aligned with longer-term green growth plans and the transition towards a low-carbon economy. ${ }^{15}$ The US President's Climate Action Plan announced in June 2013 provides an example of how information on a government's domestic and international efforts to address climate change can be presented (see Box 3). Providing information of this type can help to build trust between countries while strengthening the negotiating position of the reporting country.

\section{Box 3: The US Climate Change Action Plan}

In June 2013, US President Barack Obama gave a speech on climate change and announced a new Climate Change Action Plan (White House, 2013). The plan reiterates that the President remains "firmly committed" to the pledge first made by the US Administration in 2009 to reduce GHG emissions in the range of $17 \%$ below 2005 levels if other major economies agree to limit their emissions. The plan outlines the various domestic policy measures that the administration intends to take in order to reach this goal. These include the establishment of emissions standards for new and existing coal-fired power plants, making up to USD 8 billion of loan guarantees available for advanced fossil energy and efficiency projects, increased deployment of renewable energy, a goal to make nonfederal buildings $20 \%$ more energy efficient by 2020 , a goal to reduce GHG emissions from consumer appliances and federal buildings by 3 billion tonnes cumulatively by 2030, new fuel economy standards, a commitment to develop a methane strategy, and a commitment to protect American forests.

The plan also provides information on the various international initiatives to tackle climate change being supported by the US government, in addition to the UNFCCC process. These include the Major Economies Forum on Energy and Climate, bilateral co-operation with key emerging economies such as China, India and Brazil, the Climate and Clean Air Coalition to Reduce Short-Lived Climate Pollution, Reducing Emissions from Deforestation and Forest Degradation, the US-Africa Clean Energy Finance Initiative, the US-Asia Pacific Comprehensive Energy Partnership, the Carbon Sequestration Leadership Forum, the Clean Energy Ministerial, and working towards reducing tariffs on environmental goods in the World Trade Organisation.

Governments could also clarify if they intend to meet part of their commitments by purchasing GHG units from international market mechanisms to offset some of their domestic emissions. If so, information could be provided (to the best extent possible) on the scale of use envisaged (e.g. the maximum percentage of the commitment to be met by units from market mechanisms), as well as the

\footnotetext{
${ }^{15}$ For many developing countries, climate change adaptation is a higher policy priority than mitigation. Therefore some countries may also choose to provide information on implementation of national adaptation policies and the links between adaptation and mitigation actions.
} 
source of the units (e.g. units from the NMM or other units recognised by the FVA). Clarity on the approach used for accounting for flows of units is important if units coming from outside the boundary of the commitment concerned are used (either from another country, a non-covered sector or gas, or banked or carried over from an earlier period).

Further, given the broad participation envisaged for the 2015 agreement, there is likely to be an increasing number of cases where GHG units are created and exported from countries that have taken on mitigation commitments (including countries who have not previously had commitments under the Kyoto Protocol). In these cases, those countries should clarify whether (and if so, how) the emissions reductions associated with sold units are treated in the national GHG inventory and in measuring progress towards their commitments.

\section{Possible process for establishing post-2020 commitments}

Broad agreement has emerged on the objectives and principles of the 2015 agreement (UNFCCC, 2013a). The next step will be to begin to consider the details of the new agreement and the process used to establish commitments. The process could include multiple stages, resulting in the inclusion of commitments in the new agreement at COP 21 in 2015.

The 2015 agreement is likely to contain a combination of nationally-determined and internationallyagreed elements. Nationally-determined elements are needed to encourage broad participation in the process and ensure that the agreement respects the sovereignty of nation states. At the same time, internationally-agreed elements are needed to ensure that the overall agreement is perceived to be fair, transparent and applicable to all, and that the collective ambition of commitments is consistent with the $2{ }^{\circ} \mathrm{C}$ long-term global goal. The key question is not therefore to decide whether the 2015 agreement should be "bottom up" or "top down"; it is which elements of the new agreement should be nationally-determined, which should be internationally-agreed, and what the role of the international negotiations is in both cases.

\subsection{The multiple influences on mitigation commitments}

There are multiple stages involved when setting mitigation goals (WRI, 2013a). When designing the process for establishing commitments for the 2015 agreement, it will be important to bear in mind the multiple domestic and international influences on climate policy processes. Establishing a mitigation commitment is a sovereign decision that is taken by the government in each country, and the process for setting commitments can be different in every country. However, a general set of common international and domestic influences can be identified (see Figure 5). 
Figure 5. Common international and domestic influences on mitigation commitments

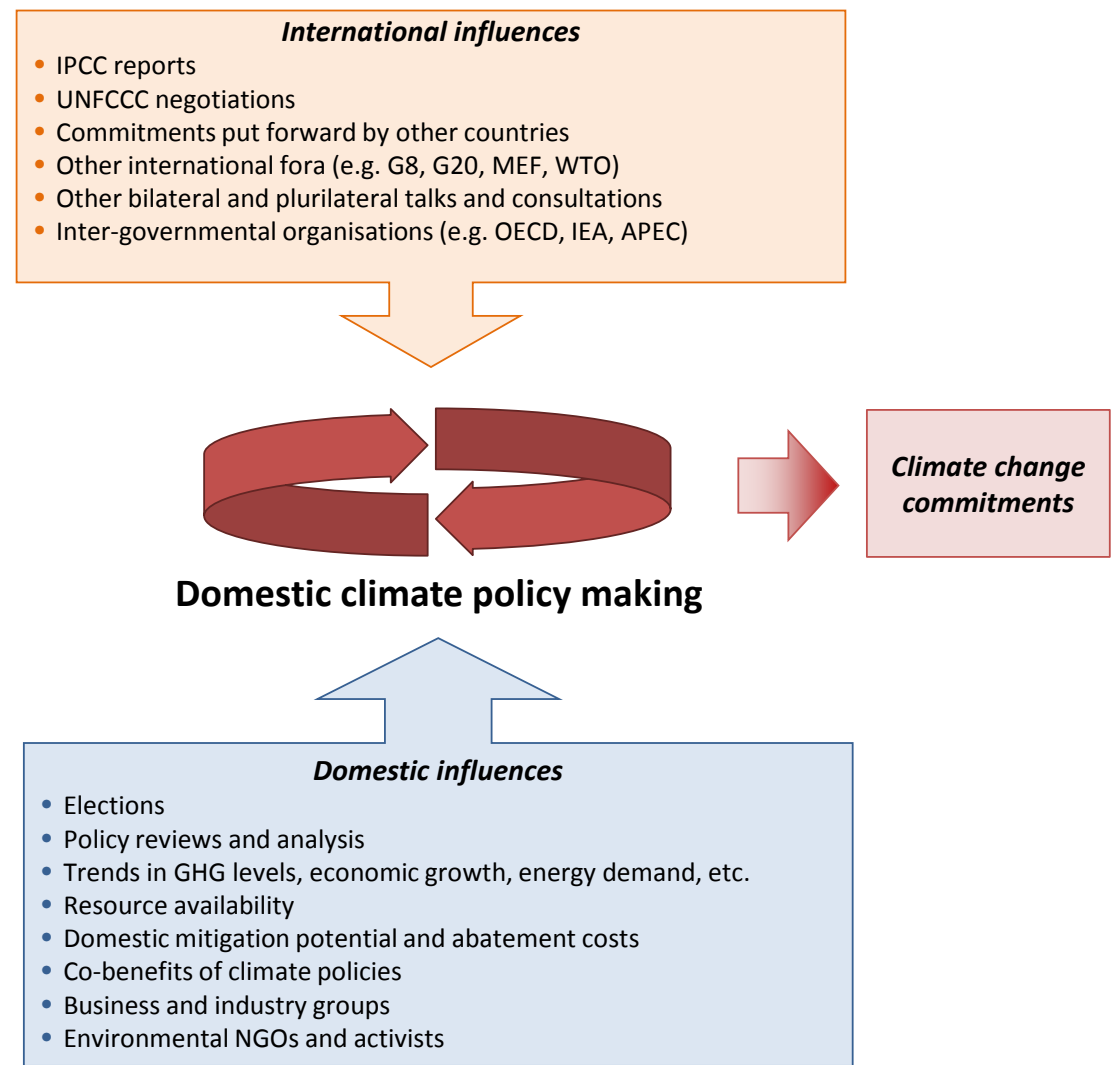

At the international level, the IPCC's assessment reports are likely to be an important influence on the level of ambition of commitments. For example, references have been made in the UNFCCC negotiations (e.g. the submission by Nauru in UNFCCC, 2012c) to the findings of the IPCC Fourth Assessment Report, which estimated that aggregate emissions reductions of 25-40\% from 1990 levels by 2020 for Annex I Parties and a substantial deviation from the baseline in non-Annex I countries are consistent with a $450 \mathrm{ppm}$ scenario (IPCC, 2007a). The contribution of IPCC Working Group III (mitigation) to the fifth assessment report is due for approval in April 2014. The numbers that will be contained in this document could be an influential factor on the overall level of ambition of commitments for the 2015 agreement.

The UNFCCC process itself and the commitments put forward by other countries under the UNFCCC can help to maintain pressure on governments to pursue ambitious climate commitments. In addition to the other international initiatives outlined in Section 3, bilateral and plurilateral initiatives, such as joint projects to tackle certain categories of GHGs or to link together carbon markets, can facilitate the achievement of mitigation commitments and thereby promote ambition. Intergovernmental organisations such as the OECD, the IEA and regional organisations can also support governments in their efforts to develop and implement climate policies and provide a basis for enhancing co-operation between countries (see, for example, OECD, 2013).

At the domestic level, changes of government can clearly be important influences and election cycles or leadership changes can influence the timing of decisions on flagship climate policy developments. Climate policy reviews or analysis may also be commissioned by governments with the aim of 
informing the government's position. For example, the Stern Review commissioned by the UK government in 2006 presented an economic case for early action on climate change and became a key influence on government policy in the UK and elsewhere (UK House of Commons, 2008). Similarly, the Garnaut Climate Change Review commissioned by the Australian Government in 2008 recommended that Australia should adopt a target of a 5\%, $10 \%$ or $25 \%$ reduction from 2000 levels by 2020 depending on the actions of other major economies and the level of ambition of the global agreement (Garnaut, 2008). Australia's subsequent pledge for 2020 under the Cancun Agreements was very similar to this recommendation.

Important steps towards developing a climate change commitment can be the development of an emissions inventory and a climate change plan or strategy. ${ }^{16}$ For example, Kenya launched its National Climate Change Action Plan (NCCAP) in March 2013. The first stage of the action plan was to create an up-to-date and comprehensive GHG emissions inventory for the years 2000-2010 (Government of Kenya, 2013). Furthermore, some of the nationally appropriate mitigation actions submitted by developing countries under the Cancun Agreements include the development of an emissions inventory or climate change plan at the national or sector level (e.g. Afghanistan, Côte d'Ivoire, Eritrea, Georgia, the Gambia, Madagascar) (UNFCCC, 2013b).

Climate policy making may also take into account resource availability and domestic mitigation potential and abatement costs. Actions that contribute towards climate change mitigation or adaptation often address multiple domestic policy priorities, such as improvement of air quality, health benefits, increased energy independence and improvement of access to electrification. These broader benefits can help to bolster the case for more ambitious climate action. Further, business groups, environmental activists, academia and other civil society groups can also have loud voices in domestic climate policy debates.

\subsection{Possible stages of the process}

Some countries have outlined possible stages of the process for establishing post-2020 commitments in recent submissions to the ADP (UNFCCC, 2013c). Based on these submissions, as well as the discussion in Section 3 of this paper, Figure 6 outlines one possible approach for the process, while recognising that many different approaches are possible. Some of the stages could overlap (e.g. the discussion of ex-post accounting rules could take place in parallel with the submission of draft commitments). Work on increasing the level of ambition (or "ratcheting-up") of draft commitments ${ }^{17}$ might be needed both before and after reaching an agreement in 2015. Work on the ex-post accounting system might need to continue after 2015. Provisions could also be included for updating commitments after 2015, in order to ensure that they remain relevant and ambitious when they come into effect in 2020 and beyond. Note that while bounded flexibility may apply to the mitigation commitments put forward, the stages of this process would be the same for all participating countries.

\footnotetext{
${ }^{16}$ Note that the metrics used to measure progress towards domestic climate policy objectives can be different to those used to measure progress towards international commitments in the context of the UNFCCC.

${ }^{17}$ In this paper, “draft commitments” refer to indications by countries before COP 21 of the commitments that they intend to include in the 2015 agreement, i.e. tentative mitigation commitments that are not yet included in the 2015 agreement.
} 
Figure 6. A possible process with multiple stages

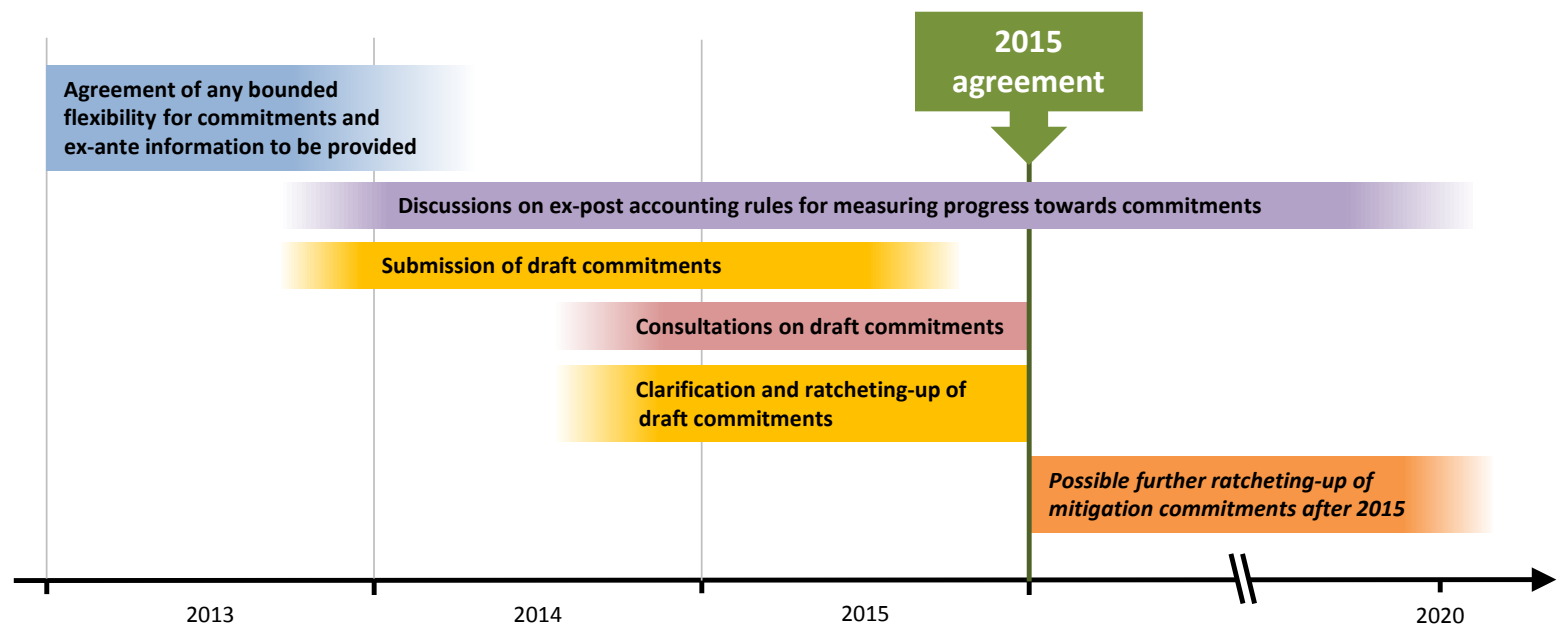

\section{Establishment of international guidance for draft commitments}

If countries agree to bounded flexibility for some dimensions of commitments, then details of this would need to be agreed before draft commitments are put forward. As outlined in Section 3, guidance could also be provided regarding what ex-ante information should be submitted alongside draft commitments in order to understand them. If draft mitigation commitments are to start being submitted in 2014, then ideally such guidance would be agreed before then (i.e. at COP 19 in Warsaw).

In the absence of an agreement at COP 19 on bounded flexibility and the ex-ante information to be provided for mitigation commitments, there are two possibilities. The first possibility is that countries continue to seek agreement on this topic in 2014, and the submission of draft mitigation commitments is delayed. This would decrease the time available for the consultations stage. The second possibility is that draft mitigation commitments are put forward before guidance for the commitments has been agreed. This case would resemble the 2020 pledges process in that commitments would be put forward with little or no international guidance in place, and there would be a greater focus on ex-post clarification exercises.

While work on ex-ante guidance for mitigation commitments needs to be completed as soon as possible, work on the accounting rules used to measure ex-post progress towards commitments could continue after 2015. Countries would need to decide if some aspects of the accounting system would be locked in for the duration of the commitment time frame (e.g. GWPs from the IPCC fourth assessment report are to be used for accounting throughout the time frame) or if they would be updated as new information becomes available (e.g. GWPs from any future IPCC assessment reports are to be used once this information is published).

Whatever form the guidance takes, it will need to be flexible enough to reflect the different national circumstances of countries and could contain tiers or exceptions for some countries (e.g. emissions projections for smaller developing countries could be encouraged but not mandatory). At the same time, while flexibility is important for ensuring broad participation in an agreement, it should not be pursued at the expense of environmental integrity and should not provide a loop-hole that allows countries to put forward weak or opaque commitments under the 2015 agreement.

\section{Submission of draft commitments}


The purpose of this stage would be to provide an indication of the commitments that countries intend to undertake before the commitments are included in the 2015 agreement. The submission of the draft commitments should be accompanied by the ex-ante information needed to understand them, in accordance with any agreed international guidance. The draft commitments and ex-ante information could be made publicly available on the UNFCCC website.

In order to leave sufficient time for international consultations to take place, national governments will probably need to formulate and submit draft commitments in 2014. Thus countries may wish to begin their domestic processes for considering and preparing draft mitigation commitments as soon as possible. This process can involve the evaluation of abatement potential and costs, as well as the development of emissions projections, at the economy-wide or sector scale. Some developing countries may require technical and financial support to complete this.

\section{International consultations on draft commitments before 2015}

One of the stages of the process could be a period of international consultations on the draft commitments before they are included in the 2015 agreement. The purpose of this stage could be to provide a space for country governments and other stakeholders to ask questions and improve their understanding of the draft commitments proposed by other countries, to give the country concerned an opportunity to provide further clarity on how its proposed draft commitment is fair and ambitious, and to identify options for raising the level of ambition of commitments. The draft commitments could continue to be clarified and updated by countries during this period, reflecting the findings of the international consultations as well as other international and domestic influences. ${ }^{18}$

By adding an element of international feedback to the process, the consultations stage could provide an incentive for countries to put forward ambitious initial draft commitments. Based on experience under the UNFCCC to date, however, it seems unlikely that the collective ambition of the nationallydetermined commitments proposed before 2015 would be within the range of pathways identified by the IPCC as consistent with the long-term global $2{ }^{\circ} \mathrm{C}$ goal. The consultation period could also therefore provide a source of peer pressure to raise the level of ambition of draft commitments before they are included in the 2015 agreement, ${ }^{19}$ as well as to implement domestic legislation to meet these commitments. The extent to which such an exercise could have an impact on domestic target-setting processes remains unclear and will vary between countries, particularly if draft commitments have already been enshrined in domestic legislation. If a country's draft commitment includes a range of values, it is possible that the consultations process could encourage the country to move towards the more ambitious end of the range.

If draft commitments are to be updated before 2015, Parties would need to decide whether they may be revised upwards only (i.e. made more stringent), or revised either upwards or downwards. The former option might prevent governments from attempting to weaken (or "backslide" from) their previously-stated commitments. However, it also would provide an incentive to propose weaker draft commitments initially. Enabling countries to revise their commitments in either direction could encourage countries to propose more ambitious draft commitments, but would of course allow the possibility for governments to lower their level of ambition later on. Figure 6 illustrates the "ratcheting-up" option.

\footnotetext{
${ }^{18}$ If draft commitments are still not collectively stringent enough to achieve a $2{ }^{\circ} \mathrm{C}$ global emissions trajectory, an alternative possibility is that a set of commitments could be generated by the international community with countries choosing commitments from the set according to their national circumstances.
}

\footnotetext{
${ }^{19}$ Note that a separate review of the $2{ }^{\circ} \mathrm{C}$ long-term global goal itself will also be taking place in 2013-2015.
} 
There are a range of different options for how the consultations could be conducted. For example, the consultations could take place inside or outside the UNFCCC. Further, the consultations could consider studies prepared by independent international organisations or institutes, in addition to information provided by country governments. The international consultations process could also catalyse national consultation processes in different countries, which in turn could help to broaden the participation of domestic stakeholders in the development of mitigation commitments.

Any consultation exercise under the UNFCCC could build on existing MRV processes, such as reporting via biennial reports and biennial update reports as well as verification via international assessment and review (IAR) and international consultations and analysis (ICA) ${ }^{20}$ However, it could be difficult to incorporate the consultations exercise for post-2020 commitments into the IAR and ICA processes because they have different objectives - specifically, IAR and ICA will consider progress made towards mitigation targets and actions, but not the level of ambition of the targets and actions themselves. Therefore a new, separate process for international consultations on post-2020 commitments is likely to be needed.

There are currently 195 Parties to the UNFCCC. If a consultation process were to be undertaken for all countries, this would have significant implications in terms of time and resources. The number of consultations undertaken could be reduced by conducting consultations for groups of countries or making the process voluntary for small emitters (e.g. least developed countries and small island developing states). Another way to minimise resource use could be conduct international consultations electronically via the internet, as the European Commission regularly does for its internal policy process (see Box 4).

\section{Box 4: European Commission public consultations on climate policy}

The European Commission has a long-standing tradition of conducting online public consultations on its climate policies. Six online consultations were conducted in 2013, including a consultation on the shape of the 2015 agreement as well as the EC's 2030 framework for climate and energy policies (EC, 2013). The length of the period of consultation is generally around 2-3 months. A separate webpage is set up for each consultation containing information on the objective and questions posed by the consultation, together with links to any relevant documentation.

Responses can be submitted by organisations and public authorities as well as citizens. Organisations are asked to register and provide information on who they are and what they represent before submitting a contribution. Responses are submitted electronically via the website and subsequently uploaded to the consultation webpage. This method allows significant numbers of responses to be submitted and managed. For example, for a consultation on reducing $\mathrm{CO}_{2}$ from road vehicles held in 2011, a total of 3233 contributions were received via the online questionnaire (EC, 2011). The consultation was conducted in English, French and German. If international consultations under the UNFCCC were conducted using a similar online platform, care would need to be taken to ensure that documents are provided in the appropriate languages.

\section{Incorporating commitments into the 2015 agreement}

\footnotetext{
${ }^{20}$ The scope of biennial reports and IAR for developed countries includes information on GHG emissions and trends, mitigation targets, progress towards mitigation targets, emissions projections and support provided. The scope of biennial update reports and ICA for developing countries includes the GHG inventory, mitigation actions and support needed/received.
} 
Following consultations on the draft commitments, the next stage of the process would be the inclusion of the commitments in the 2015 agreement. There are various ways in which this could be achieved, e.g. the commitments could be included in the core agreement, in an annex to the agreement, in separate INF documents, or in a separate COP decision. Listing the commitments in an annex to the 2015 agreement or a set of COP decisions, rather than as part of the core agreement itself, could make them easier to subsequently modify. The commitments included in the 2015 agreement could only be the first round of a longer-term process of setting mitigation commitments, with a view to achieving the long-term $2{ }^{\circ} \mathrm{C}$ global goal.

\section{Further ratcheting-up of mitigation commitments after 2015}

In order to ensure that the mitigation commitments included in the 2015 agreement remain relevant and ambitious once the agreement comes into effect from 2020, provisions could be included to allow further consultations and ratcheting-up of commitments in the period 2015-2020 (i.e. before the agreement has come into effect), as well as after 2020. The UNFCCC process and international peer pressure could play an important role in encouraging governments to raise the level of ambition of their commitments when domestic political conditions allow.

The ratcheting-up process could include some form of periodic review or consultations on commitments. The periodic review or consultation could have both substantive dimensions (e.g. consideration of commitments in light of the latest climate science) and procedural dimensions (e.g. the timeline and who undertakes the process). However, it would be challenging for all countries to synchronise their potential revisions of commitments because the length of policy cycles and dates of election cycles are different in every country. As an alternative to a periodic process, therefore, governments could be free to update their commitments according to a nationally-determined timetable.

Frequent revisions of national mitigation commitments could create an unacceptably high level of risk for investors in low-carbon technologies, as well as complications for domestic policy processes. However, if commitments are not revised frequently enough, they risk becoming outdated and locking in low levels of ambition. Therefore, regardless of the approach chosen, governments would need to strike a balance between maximising opportunities to raise ambition and minimising the policy uncertainty associated with potential revisions to their climate objectives.

\section{Conclusions}

Mitigation commitments are expected to underpin the 2015 climate change agreement. A diverse range of nationally-determined mitigation commitments is likely to be put forward, reflecting the widely varying national circumstances of countries. An effective agreement would have broad participation as well as high ambition. Incentives are therefore needed to encourage countries to participate in the process and to put forward strong mitigation commitments.

There are links between mitigation commitments and climate finance. Some countries may choose to put forward packages of commitments including both mitigation and finance objectives. For many developing countries, financial, technical and capacity building support may be needed in order to implement their mitigation actions. For example, many developing countries explicitly stated that the extent to which their mitigation pledges for 2020 can be implemented depends on the provision of finance and other support (e.g. South Africa, Bhutan, Central African Republic, Colombia) (UNFCCC, 2013b). 
To facilitate post-2020 accounting, the commitments put forward would need to be clear, transparent and quantified. Commitments could be quantified in terms of a GHG-related metric where possible. This would help to inform estimates of future global GHG emissions and assessments of progress towards the $2{ }^{\circ} \mathrm{C}$ long-term global goal. It would also facilitate assessment of progress towards individual country commitments. It is difficult to see how an agreement with legal force could be achieved without quantified commitments that are measurable. However, commitments may not necessarily be quantified in terms of GHG emissions; other, non-GHG metrics could be appropriate in some cases. The use of alternative metrics might help to shift the focus towards aspects of the economy over which governments typically have more control (e.g. stimulating investment in clean energy infrastructure), rather than aspects for which there are multiple drivers and trends outside of government control, such as global macroeconomics and weather conditions (e.g. total GHG emissions).

The use of mitigation commitments expressed using metrics other than annual or cumulative GHG emissions increases the uncertainty associated with future GHG emissions trajectories. In particular, while commitments expressed relative to BAU levels can enable a government to commit to reduce emissions without taking on an absolute emissions reduction target, these types of commitments pose particular challenges for emissions accounting. This is because the hypothetical nature of BAU baselines and the possibility of baseline revisions constitute significant additional sources of uncertainty regarding the future target level of GHG emissions. If some post-2020 commitments are expressed relative to BAU baselines, they would need to be accompanied by detailed information on the underlying BAU baseline projection. It would also be helpful to have some degree of international convergence on the approach to be used for calculating national BAU baselines.

Parties could agree on a level of bounded flexibility (i.e. agreed values or ranges) for some dimensions of commitments, in order to facilitate emissions accounting and assessment of progress towards individual and global goals. In particular, Parties could agree the time frame and GWPs or other GHGequivalence metric to be used for commitments. It is possible that bounded flexibility could also be negotiated for other dimensions of mitigation commitments, depending on the varying national circumstances of countries. For some dimensions, countries could agree to transparency requirements if it is not possible to agree bounded flexibility.

The ex-ante clarification of commitments could play an important role in building trust between countries and providing a clearer picture of expected progress towards the $2{ }^{\circ} \mathrm{C}$ global goal. Some of this information depends on the commitment type, e.g. carbon neutrality commitments should be accompanied by a definition of carbon neutrality. However, much of the information would be needed regardless of commitment types, e.g. time frame, coverage of gases and sectors, GWP values or other GHG-equivalence metrics, treatment of LULUCF, estimated emissions reductions, any conditions attached, and any use of units from market mechanisms. This ex-ante information could provide the foundation of the post-2020 emissions accounting system. Furthermore, if all major emitters were to provide an estimated range for their GHG emissions in an agreed future year (e.g. 2030), this would facilitate estimations of the future GHG emissions pathway. Information on how the government intends to meet its commitment (e.g. via domestic climate legislation and policies implemented or planned) together with an explanation of its level of ambition given national circumstances could help to further enhance understanding between countries on the actions being taken by others.

Possible stages of the process (and tentative dates) for establishing and understanding commitments could include:

- $\quad$ Agreement of bounded flexibility (if any) for some dimensions of post-2020 commitments and guidance for ex-ante information to be provided (late 2013 - early 2014) 
- Discussions on ex-post accounting rules (from late 2013)

- $\quad$ Submission of draft commitments to the UNFCCC (late 2013 - mid 2015)

- International consultations on draft commitments (mid 2014 - end 2015)

- Clarification and ratcheting-up of commitments (mid 2014 - end 2015)

- Incorporation of commitments into the 2015 agreement (end 2015)

- Further ratcheting-up of commitments (2016-2020, as well as after 2020)

The extent to which any international consultations could have an impact on domestic target-setting processes is unclear - particularly if the draft commitments have already been enshrined in domestic legislation before the consultations take place. Further, domestic climate policy planning processes are shaped by multiple domestic and international factors. While formal consultations under the UNFCCC process could help to clarify the details of draft commitments and identify potential opportunities for raising ambition, the negotiation of the headline numbers themselves may well be done outside of formal negotiations, bilaterally and with the involvement of domestic policy-makers. Opportunities for such interactions, such as the UN Secretary-General's intention to convene world leaders in 2014, should therefore be welcomed and maximised.

Effective commitments should be "future-proof" in the sense that they remain relevant to 2020 and beyond despite changing economic and social circumstances. This could be done by maintaining flexibility in the commitments included in the 2015 agreement so that governments are able to update their commitments before 2015, in the period 2015-2020, and after 2020. Parties could agree that commitments may be revised upwards or downwards, or upwards only (i.e. only made more stringent). While the latter option might prevent governments from backsliding from ambitious commitments, it might also incentivise governments to propose weaker initial commitments. It is therefore unclear at this point which option would result in greater overall mitigation ambition. Understanding of the relationship between long-term economic cycles and emissions trajectories also remains an area where further research is needed.

It also remains to be seen how much information countries will be willing to put on the table in advance of COP 21, since revealing negotiating positions before the meeting might curtail room for negotiation. For example, while some governments might submit draft ranges with different conditions attached to the lower and upper ends of the range, others might submit single numbers without disclosing their real range of possibilities. From an emissions accounting perspective, this lack of information would increase the degree of uncertainty associated with future global GHG emissions levels. However, it may be necessary in order to maximise country participation in the process.

Finally, the 2015 agreement should be kept as clear and simple as possible. While climate change is undoubtedly a complex issue, there is little value in producing a new agreement that few people can understand. The combination of clear and straightforward international provisions, together with longterm domestic legal frameworks that provide confidence that climate policies will be enforced, would also enhance the strength of the signal sent to the private sector and other investors that governments remain fully committed to achieving long-term transitions to low-carbon and climate-resilient economies. 


\section{References}

C2ES (2002), Analysis of President Bush's climate change plan, http://www.c2es.org/federal/executive/georgew-bush-climate-change-strategy

Clapp, C. and A. Prag (2012), "Projecting Emissions Baselines for National Climate Policy: Options for Guidance to Improve Transparency”, OECD/IEA CCXG Paper, http://www.oecd.org/env/cc/CCXG\%20\%282012\%293\%20National\%20Baselines.pdf

DEA, OECD and UNEP Risø Centre (2013), National GHG Emissions Baseline Scenarios: Learning from Experiences in Developing Countries, http://www.ens.dk/en/climate-co2/low-carbon-transitionunit/international-modeling/baselines/national-ghg-emissions

EC (2011), Reducing $\mathrm{CO}_{2}$ Emissions from Road Vehicles: Results of the Public Consultation, http://ec.europa.eu/clima/consultations/0012/summary_en.pdf

EC (2013), The European Commission consults the public on policy papers, http://ec.europa.eu/clima/consultations/index_en.htm

Garnaut (2008), The Garnaut Climate Change Review: Final Report, Cambridge University Press, http://www.garnautreview.org.au/index.htm

GLOBE (2013), The GLOBE Climate Legislation Study: Third Edition, http://www.globeinternational.org/images/climate-study/3rd_GLOBE_Report.pdf

Government of Brazil (2010), Decree number 7390, available in Portuguese at http://www.planalto.gov.br/ccivil_03/_Ato2007-2010/2010/Decreto/D7390.htm

Government of Kenya (2013), Kenya Launches a National Climate Change Action Plan (NCCAP), http://www.kccap.info/

Haites, E., F. Yamin and N. Hohne (2013), Possible Elements of a 2015 Legal Agreement on Climate Change, IDDRI Working Paper, http://www.iddri.org/Publications/Collections/Idees-pour-ledebat/WP1613_EH\%20FY\%20NH_legal\%20agreement\%202015.pdf

IEA (2012), $\mathrm{CO}_{2}$ Emissions from Fuel Combustion, http://www.iea.org/publications/freepublications/publication/name,32870,en.html

IPCC (2007a), Contribution of Working Group III to the Fourth Assessment Report of the Intergovernmental Panel on Climate Change, Metz, B., O.R. Davidson, P.R. Bosch, R. Dave, L.A. Meyer (eds.), Cambridge University Press, Cambridge, United Kingdom and New York, USA.

IPCC (2007b), Contribution of Working Group I to the Fourth Assessment Report of the Intergovernmental Panel on Climate Change, Solomon, S., D. Qin, M. Manning, Z. Chen, M. Marquis, K.B. Averyt, M. Tignor and H.L. Miller (eds.), Cambridge University Press, Cambridge, United Kingdom and New York, USA.

IPCC (2013), Climate Change 2013: The Physical Science Basis. Summary for Policymakers, http://www.ipcc.ch/report/ar5/wg1/

Mary Robinson Foundation (2013), Submission to the ADP by the Mary Robinson Foundation - Climate Justice, ADP Submission, March 2013, http://unfccc.int/resource/docs/2013/smsn/un/306.pdf

MEF (2013), MEF Chair's Summary, Krakow, 18 July 2013, http://www.scribd.com/doc/155484172/MEFChair-s-Summary

OECD (2012), OECD Environmental Outlook to 2050: The Consequences of Inaction, www.oecd.org/environment/outlookto2050

OECD (2013), The Climate Challenge: Achieving Zero Emissions, http://www.oecd.org/env/the-climatechallenge-achieving-zero-emissions.htm

Philibert, C. (2005a), "New Commitment Options: Compatibility with Emissions Trading, OECD/IEA AIXG Paper, http://www.oecd.org/env/cc/35798709.pdf

Philibert, C. (2005b), “Climate Mitigation: Integrating Approaches for Future International Co-operation”, OECD/IEA AIXG Paper, http://www.oecd.org/env/cc/35798756.pdf

Prag, A., C. Hood and P. Martins Barata (2013), "Made to Measure: Options for Emissions Accounting under the UNFCCC”, OECD/IEA CCXG Paper, http://www.oecd.org/env/cc/Made\%20to\%20Measure_Final.pdf 
Prag, A., G. Briner, and C. Hood (2012), "Making Markets: Unpacking Design and Governance of Carbon Market Mechanisms", OECD/IEA CCXG Paper, http://oecd.org/env/cc/(2012)4\%20\%20Market\%20Mechanisms_AE\%20(2).pdf

Sterk, W., C. Beuermann, H. J. Luhmann, F. Mersmann, S. Thomas, T. Wehnert (2013), Input to the European Commission Stakeholder Consultation on the "2015 International Climate Change Agreement: Shaping international climate policy beyond 2020” by the Wuppertal Institute for Climate, Environment and Energy, http://epub.wupperinst.org/frontdoor/index/index/docId/4927

Turner, G. (2013), The Case for Intensity-Based Targets to Curb Climate Change, Bloomberg New Energy Finance VIP Brief, 27 March 2013, http://about.bnef.com/blog/turner-the-case-for-intensity-based-targets-tocurb-climate-change/

UK House of Commons (2008), Climate change and the Stern Review: the implications for Treasury policy, http://www.publications.parliament.uk/pa/cm200708/cmselect/cmtreasy/231/231.pdf

UNDESA (2011), World Population Prospects: The 2010 Revision, http://esa.un.org/wpp/

UNEP (2012), The Emissions Gap Report 2012, http://www.unep.org/publications/ebooks/emissionsgap2012/

UNEP (2013), Summary of control measures under the Montreal Protocol, http://ozone.unep.org/new_site/en/Treaties/treaties_decisionshb.php?sec_id=6,7,8,9,10,11,12,13,14,15,16,17,18,19,20,21,22,23,24

UNFCCC (2002), Guidelines for the preparation of national communications from Parties not included in Annex I to the Convention, decision 17/CP.8, http://unfccc.int/resource/docs/cop8/07a02.pdf\#page=2

UNFCCC (2009), Ideas and proposals on the elements contained in paragraph 1 of the Bali Action Plan: Submissions from Parties: Addendum, FCCC/AWGLCA/2009/MISC.1/Add.3, http://unfccc.int/resource/docs/2009/awglca5/eng/misc01a03.pdf

UNFCCC (2011a), Decisions adopted by the Conference of the Parties, Report of the Conference of the Parties on its sixteenth session, held in Cancun from 29 November to 10 December 2010, http://unfccc.int/resource/docs/2010/cop16/eng/07a01.pdf

UNFCCC (2011b), Compilation of economy-wide emission reduction targets to be implemented by Parties included in Annex I to the Convention, FCCC/SB/2011/INF.1/Rev.1, http://unfccc.int/resource/docs/2011/sb/eng/inf01r01.pdf

UNFCCC (2012), Additional information relating to the quantified economy-wide emission reduction targets contained in document FCCC/SB/2011/INF.1/Rev.1. Submissions from Parties. FCCC/AWGLCA/2012/MISC.1, http://unfccc.int/resource/docs/2012/awglca15/eng/misc01.pdf

UNFCCC (2013a), Progress towards bridging the pre-2020 ambition gap and delivering a new agreement by 2015. Note by the Co-Chairs. http://unfccc.int/resource/docs/2013/adp2/eng/14infnot.pdf

UNFCCC (2013b), Compilation of information on nationally appropriate mitigation actions to be implemented by Parties not included in Annex I to the Convention, Revised note by the secretariat, FCCC/SBI/2013/INF.12/Rev.2, http://unfccc.int/resource/docs/2013/sbi/eng/inf12r02.pdf

UNFCCC (2013c), Quantified economy-wide emission reduction targets by developed country Parties to the Convention: assumptions, conditions, commonalities and differences in approaches and comparison of the level of emission reduction efforts, http://unfccc.int/resource/docs/2013/tp/07.pdf

UNFCCC (2013c), Submissions from Parties to the ADP, http://unfccc.int/bodies/awg/items/7398.php

White House (2013), The President's Climate Action Plan, http://www.whitehouse.gov/sites/default/files/image/president27sclimateactionplan.pdf

WRI (2007), China's Carbon Intensity Target, http://www.wri.org/stories/2007/04/chinas-carbon-intensitytarget\#

WRI (2013a), Mitigation Goals Standard: Second Draft for Pilot Testing, http://www.ghgprotocol.org/mitigation-accounting

WRI (2013b), World Resources Institute (WRI) ADP Submission - Track 1, ADP Submission, March 2013, http://unfccc.int/resource/docs/2013/smsn/ngo/304.pdf

Zhang, S. and N. Bauer (2013), “Utilization of the non-fossil fuel target and its implications in China”, Climate Policy, Vol. 13, No. 3, 328-344, http://dx.doi.org/10.1080/14693062.2013.768929 


\section{Glossary}

ADP Ad hoc Working Group on the Durban Platform for Enhanced Action

AI Developed countries listed in Annex I of the UNFCCC

BAU Business As Usual

BR Biennial report (developed countries)

BUR Biennial update report (developing countries)

COP Conference of the Parties to the UNFCCC

EU ETS European Union Emissions Trading System

GDP Gross Domestic Product

GHG Greenhouse Gas

GTP Global Temperature Potential

GWP Global Warming Potential

IAR International Assessment and Review (developed countries)

ICA International Consultations and Analysis (developing countries)

ICAO International Civil Aviation Organisation

IMO International Maritime Organisation

ITL International Transaction Log

JI Joint Implementation

KP Kyoto Protocol

LDC Least Developed Country

LULUCF Land Use, Land-use Change and Forestry

MEF Major Economies Forum on Energy and Climate

MRV Measurable, Reportable and Verifiable

NAI Developing countries that are not listed in Annex I of the UNFCCC

SBI Subsidiary Body for Implementation

SBSTA Subsidiary Body for Scientific and Technological Advice

UNFCCC United Nations Framework Convention on Climate Change

WTO World Trade Organisation 


\section{www.oecd.org/env/cc/ccxg.htm}

\section{www.iea.org}

